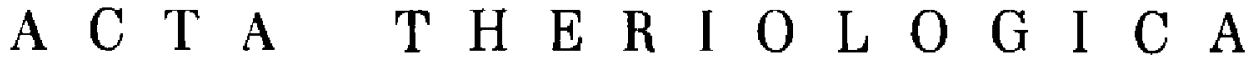

\author{
Wladysław GR O D Z I N S I *
}

\section{Energy Flow Through Populations of Small Mammals in the Alaskan Taiga Fores***}

[With 17 Tables \& 7 Figs.]

\begin{abstract}
The primary net production and the numbers of small mammals were estimated in a white spruce forest (Picea glauca). Daily metabolic rates and food habits were studied in the voles (Clethrionomys rutilus, Microtus oeconomus), squirrels (Tamiasciurus hudsonicus, Glaucomys volans) and shrews (Sorex cinereus). Production of this taiga forest amounts to only $10.2 \mathrm{miIlion} \mathrm{kcal} / \mathrm{ha}$ year. Due to different food habits of small mammals their total food available in the forest reaches as mich as $1,320,000 \mathrm{kcal} / \mathrm{ha}$ (i. e. $12.9 \%$ of primary production). Daily energy budgets deseribed by functions of body size give the following mean values: $S$. cinereus $-8.3 \mathrm{kcal}, C$. rutilus $-12.2 \mathrm{kcal}, M$. oeconomus $15.1 \mathrm{kcal}, G$. sabrinus $-39.6 \mathrm{kcal}$ and $T$. hudsonicus $-58.4 \mathrm{kcal} / \mathrm{day}$. The mean numbers of small mammals were found to be about 15 voles of both species, 2-3 squirrels and 4 shrews per 1 hectare. The total annual production of these populations was estimated as approx. 2,500 $\mathrm{kcal} / \mathrm{ha}$, their assimilation - 143,900 kcal, and consumption - 178,600 kcal. During the population cycle of voles and squirrels all these values can fluctuate within a broad range; production $600-8,000$, assimilation $38,000-400,000$, consumption $47,000-500,000 \mathrm{kcal} / \mathrm{ha}$ year. In different years small mammals may therefore consume from 3 to $38 \%$ of the potential food supply provided by the taiga forest. These values are considerably higher than those found in any other woodland.
\end{abstract}

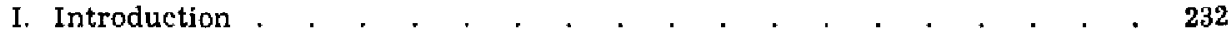

II. Materials and methods

1. Study area

2 Estimation of plant production . . . . . . . . . 233

3. Census of small mammals . . . . . . . . . . . . . . . . . 233

4. Food habits. . . . . . . . . . . . . . . 234

III. Results

Results
1. Primary production of the taiga forest . . . . . . . . . . . 236

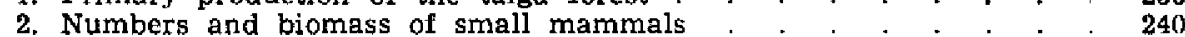

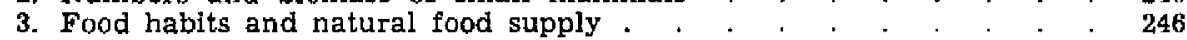

4. Daily metabolism of small mammals . . . . . . . . . . . . $\quad 252$

* Permanent adress: Department of Animal Genetics and Organic Evolution, Jagiellonian University, Kraḱow 2, Krupnicza 50, Poland.

** Publication from the Institute of Arctic Biology, Universtity of Alaska. Fairbanks (College), Alaska. 


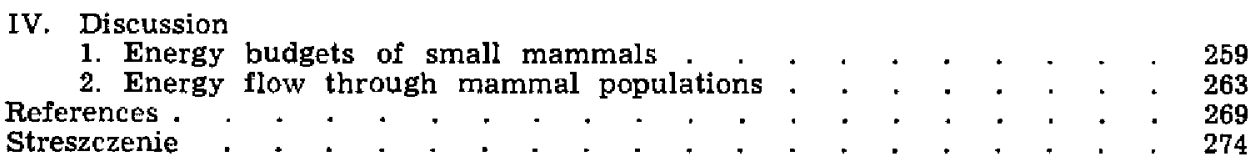

\section{INTRODUCTION}

The taiga is a circumboreal belt of predominantly spruce forests which cover not only the interior of Alaska but also considerable parts of Canada and Scandinavia as well as the northern territories of the Soviet Union. The taiga has the lowest net primary production of all forest ecosystems (Ovington, 1965; Rodin \& Basilevic, 1968) but it is inhabited by an abundance of mammals and especially small rodents (Novikov, 1956). The numbers of rodents undergo dramatic fluctuations with a cycle of several years (Ka lela, 1962; Koshkina, 1966).

The purpose of this investigation has been to estimate the balance of energy flow through populations of rodents and shrews in the subarctic alaskan taiga. The energy requirements, consumption and assimilation I) of small mammals were than compared with that part of the forest production which is available to them, i.e. with their potential food supply. Such comparison provides at least a preliminary answer as to whether quantity of food can control the population of rodents in the forest.

Almost all field and laboratory materials were collected during one growing season, in 1963. The study was conducted on a white spruce forest near College (Fairbanks), Alaska, and small mammals typical for this ecosystem were used. Two vole species, two squirrels and one shrew were selected, namely the northern red-backed vole, Clethrionomys rutilus dawsoni ( $\mathrm{M}$ e $\mathrm{r} \mathrm{i}$ a $\mathrm{m}, 1888$ ); the tundra vole, Microtus oeconomus macfarlani M e $\mathrm{r}$ ia m, 1900; the red squirrel, Tamiasciurus hudsonicus preblei A. H. How ell, 1936; the northern flying squirrel, Glaucomys sabrinus yukonensis (O s good, 1900) and the masked shrew, Sorex cinereus hollisteri $\mathfrak{J}$ a $\mathrm{ck}$ s o $\mathrm{n}, 1925$.

The study consisted of: (1) estimation of the forest primary production and its food supply for small mammals, (2) estimation of the numbers of small mammals, (3) measurements of the daily metabolism and bioenergetics of these animals, and (4) studies on their food habits and food consumption. Some data concerning metabolism has already been published (G r odziński, 1966).

1) Ecologic terminology of secondary productivity according to Petrusewicz (1967) and IBP list of recommended terms and definitions (IBP News, 10: 6-8, 1968). 


\section{MATERIALS AND METHODS}

\section{Study Area}

Field studies were carried out in a stand of white spruce located some $3 \mathrm{~km}$ $\mathrm{NW}$ of the campus of the University of Alaska (approximately: $64^{\circ} 50^{\prime} \mathrm{N}$ lat, $147^{\circ} 50^{\prime}$ W long). This forest is a part of the Alaska College Experimental Farm, includes Silvicultural Sample Plot No. 1 of the Forestry Sciences Laboratory and occurs on a southern slope approximately $190 \mathrm{~m}(600-650 \mathrm{ft})$ above sea level. It is a forest typical of the well-drained upland of the Alaskan interior ( $L$ u tz, 1956) dominated by white spruce (Picea glauca) with admixtures of black spruce ( $P$. mariana), quaking aspen (Populus tremuloides), paper birch (Betula papyrifera) and some willows (Salix spp.). In this 60 - to 80 -year-old stand the trees were about $15 \mathrm{~m}$ tall. A one hectare (2.471 acres) plot was established in this forest and used for studying both the primary net production and the numbers of simall mammals.

\section{Estimation of Plant Production}

An attempt was made to determine net primary production of the forest wfrom the point of views of a vole or a squirrel rather than a trained botanist. Thus the study was concerned primarily with the ground flora and smaller shrubs, and of the tree layer only the seed rain was considered.

The herb layer was sampled as suggested in the first instruction sheet of IBP (Ovington, 1962). In the study area twenty points were randomly spaced and permanently marked. Around each point samples were taken by clipping all above ground vegetation in quadrat $25 \times 25 \mathrm{~cm}\left(=0.0625 \mathrm{~m}^{2}\right)$ outlined by a metal frame. This material was divided into four categories (lichens, mosses, herbs, leaves and sprouts of shrubs) and dried separately. Clipped quadrats were taken every 3 to 4 weeks from May to August. Annual net production was calculated from changes in the standing crop throughout the growing season ( $O \mathrm{~d} \mathrm{u} \mathrm{m}, 1960)$.

In addition, all berries and mushrooms were collected several times from larger quadrats $\left(10 \mathrm{~m}^{2}\right.$ and $\left.100 \mathrm{~m}^{2}\right)$. The seedfall was measured for the whole year by the Northern Forest Experimental Station (Forestry Sciences Lab.) using square meter seed traps.

Dry weight and caloric value of all plant materials was determined. Plants were dried for $48 \mathrm{hr}$. at $105^{\circ} \mathrm{C}$ and the small ground samples were burned in a Parr oxygen bomb calorimeter (G oll ey, 1961).

\section{Census of Small Mammals}

Numbers of small mammals were estimated from early spring to the beginning of autumn (middle May - middle August). The reproductive season of backed voles and red squirrels falls for just this period (Se a lander, 1967; C. S mith, 1968). Vole and shrew populations were sampled by live-trapping, capture-recapture methods, whereas the estimation of squirrel numbers was based on direct observations and/or counting of middens.

The one hectare plot (cf. "Study area $x$ ) was gridded with 10 lines and 10 rows in 10 meter spacing between traps (100 trap stations). Trap positions were permanently marked. Sherman live-traps were used with smoked bacon and sunflower 
seeds as a bait. The trap position was sprebaited by some additional sunflower seeds. Nesting material consisting of cotton-wool or dried moss was provided in the traps in order to reduce trap mortality. The grid was operated for 5 consecutive days during three periods (May 14-18, July 1-5, August 10-14). The traps were examined once a day and animals were marked by toe-clipping and released in the place of capture. After the last series of capture-recapture trapping the same traps were employed for a three day removal trapping (August 15-17).

The capture-recapture estimates were made by simple counting of the minimum number alive from a wcalendar of catches (Petrusewicz \& Andrzejew$\mathrm{ski}, 1962)$, and by Jolly (1965) stochastic procedure. The calendar of catches was drawn continuously for three periods of trappings, whereas for the Jolly (1965) approach each trapping period was considered separately. The removal data were calculated by $\mathrm{Zippin}$ (1956) method of maximum likelihood ( $\mathrm{J}$ a $\mathrm{ni}$ in, Ryszkowski \& Wierzbowska, 1968).

The squirrels were observed on the same plot and in its nearest surroundings. The observations were carried out both during trapping of voles and shrews and during botanical studies (Table 1). This was fairly easy in respect of red squirrels, which are strictly diurnal, quite active and with loud vocalisation.

Table I

Animals used for measurements of $A D M R$ and the total number of daily runs.

\begin{tabular}{|l|c|r|c|c|}
\hline \multicolumn{1}{|c|}{ Species } & $\begin{array}{c}\text { No. of animals } \\
\left(0^{*} 0^{*}+\varphi\right)\end{array}$ & $\begin{array}{c}\text { Body weight, } \\
\text { Avg. }\end{array}$ & $\begin{array}{c}\text { No. of daily runs } \\
\text { actual range }\end{array}$ & at $10^{\circ}$ and $15^{\circ} \mathrm{C}$ \\
\hline S. cinereus & $7(4+3)$ & 3.9 & $3.2-5.1$ & 10 \\
C. rutilus & $16(10+6)$ & 24.4 & $190-32.8$ & 20 \\
M. oeconomus & $15(8+7)$ & 26.9 & $16.9-38.0$ & 21 \\
G. sabrinus & $4(2+2)$ & 174.4 & $160.6-188.9$ & 10 \\
T. hudsonicus & $16(8-8)$ & 249.7 & $230.8-274.5$ & 16 \\
Totaly & 58 & - & - & 77 \\
\hline
\end{tabular}

An additional snap- and live-trapping of small mammals for feeding and metabolic studies was carried out in neighbouring spruce forests. This gave additional material for estimating average body weight (Table 7 ) and reproductive state of these animals.

\section{Food Habits}

Food preference was studied in more detail in red-backed voles (C. rutilis) and in tundra voles ( $M$. oeconomus), since natural foods eaten by squirrels ( $T$. hudsonicus, G. sabrinus) in the Alaskan spruce forests have been just recently investigated by Brink \& Dean (1966) and M. Smith (1967; 1968). For both voles the choice test (acafeteria test $\ll$ ) was employed with testing majority of plant foods actually available in the taiga forest (Drozd $\dot{z}, 1966$ ). During feeding trials the voles were kept singly in plastic cages (M or r s on, 1960) or in large jars. In subsequent three-day period they were provided with various sets of food, each consisting of 3-5 types of food. Finally, the tests with the foods previously rejected were repeated. The degree of consumption of different foods (herbs, twigs, mosses, lichens, fungi and tree seeds) was estimated daily using the scale: 0,1 , 
2 , 3. The numbers in the scale correspond approximately to the following percentages: $0=0 \%$ (food was not touched), $1=0-30 \%, 2=30-60 \%$, and $3=60-90 \%$ of food consumed (D rożdz, 1966). Besides the tested food, water ad libitum and few pellets of mouse chow (Purina) were supplied. This constituted an emergency reserve in case when the tested food was inedible.

The experiment on food preference was carried out in three series: spring (May), summer (late June and July) and autumn (August). The series in each season consisted of 16-20 voles of both species. Additional analyses of stomach contents of voles and squirrels were carried out in summer. For this purpose 28 red-backed voles were snap-trapped and 6 red squirrels were shot in the spruce forests. The stomach contents were removed, weighed and the volumetric estimates of main food items (e.g. greens, lichens, berries, animal food) were made to the nearest 10 per cent. Later these items were identified by microscopic examination of slides ( $W$ ill i a m s, 1962).

\section{Measurements of the Daily Metabolism}

Daily metabolism rate was measured as oxygen consumption in an automatic continuosly recording respirometer of close circuit system (Morrison, 1951). During the 25-28 hour runs (Morrison \& Grodzinski, 1968) the animals were kept singly in big chambers with a supply of natural food, water and nesting materials. Chambers with capacity of 10-30 liters were used for squirrels, of 2-10 liters for voles, and of about 1 liter for shrews. In respect of space such chambers exceeded markedly standards recommended for laboratory animals of the same body size (L a ne-Petter, 1957); in case of shrews and voles the standard was exceeded by $5-14$ times, and for squirrels by $2.5-6$ times. However, for very active squirrels the chambers were still too small.

All measurements were carried out in the temperature of $10^{\circ}$ and $15^{\circ} \mathrm{C}$ because the mean temperature at the forest floor in Alaskan taiga varies just in this range during summer months ( $P \times u i t t, 1957$ ). The chambers were entirely sumberged in thermostated water baths; the temperature inside chambers was periodically measured by iron-constantan thermocouples and recorded on a Leeds \& Northrup potentiometer.

The animals for metabolic studies were trapped in spruce forests. Voles and shrews were kept in cages for some days in order of psychological adjustment to captivity (Buckner, 1964; Grodzinski \& Gorecki, 1967), whereas squirrels were kept for longer period in a large enclosure in the black spruce forest (B rink \& Dean, 1966).

Directly before the run and immediately after it the mammals were weighed and their rectal body temperature was measured by YSI (Yellow Spring Instruments Co). tele-thermometer with a small (flexible) thermistor probe. During daily runs the animals slightly changed their body weight, usually losing not more than $2-5 \%$ of the initial weight, on the average. The body size of animals employed in metabolic measurements (Table 1) was close to actual mean body weights in trappable population in the taiga forests (Table 7). Altogether 77 daily runs with 58 animals were completed. Hence $7-11$ runs were made for each species, except shrews, at each temperature.

The record of oxygen consumption was read off from the chart of a multichannel Esterline-Angus operation recorder. Usually the first $1-4$ hours, as a period of adjustment, were not taken for calculations. The linear distances (time) from 
the chart were punched on cards by the Oscar Model $\mathrm{K}$ (Bensen \& Lerner). The calculations (time $\rightarrow \mathrm{ccm} / \mathrm{h} \mathrm{hr}$ ) were then carried out on the IBM 1620 digital computer. The results come from 1620 in the form of cards which are then listed by the IBM 407 printer. These same cards were then reprocessed by the 1620 to give 24-hour and 6-hour cycles, daily totals, and other statistical analysis.

\section{RESULTS}

\section{Primary Production of the Taiga Forest}

In interior Alaska the growing season is only three months long. In the taiga the prevernal season begins in the second half of May; phenologic spring lasts from the end of May until the middle of June; summer is at its peak in July and true fall begins as early as the second half of August or at the beginning of September.

In the area studied in 1963 the snow cover had disappeared completely by May 11th. During the prevernal season forest floor vegetation consisted mostly of mosses (Hylocomium splendens, Pleurozium schreberi and Polytrichum sp.), lichens (Peltigera apthosa, Cladonia orbuscula, C. rangiferina) and low evergreen shrubs e.g. Vaccinium vitis-idaea, Empetrum nigrum, Ledum groenlandicum. In the early spring there was a rapid development of herbs (e.g. Equisetum pratense, Linnaea borealis, Mertensia paniculata, Cornus canadensis) while shrubs (Viburnum edule, Rosa acicularis, Sheperdia canadensis) and deciduous trees produced new leaves. In the herb layer the peak of development and blooming took place at the beginning of summer. At this time, in addition to the herbs mentioned, Geocaulon lividum, Epilobium angustifolium, Lycopodium annotinum were abundant, and Pyrola sp., Goodyera repens, Astragalus alpinus and Aconitum delphinifolium were common. The berries and other fruits of many shrubs (Vaccinium vitis-idaea, V. uliginosum, Empetrum nigrum, Viburnum edule, and Sheperdia canadensis) ripened in late summer and early fall. During this period and coinciding with summer rains there was a great abundance of fungi, primarily mushrooms (Russula, Amanita, Boletus, Clavaria, Hydrophorus and Hydnum). In the fall of 1963 ground frost had developed by early September. Snowfall in this area begins usually in September or October.

To the uninitiated from lower latitudes the brief but rapid development of the taiga vegetation is spectacular. The estimation of annual primary production of the taiga forest can be made in this short period of 3-4 months. An estimation of the production of the taiga ground flora is provided in Table 2. Net production was calculated simply by subtracting the minimal from the maximal standing crop. 
This table requires additional comment. The herbs and small shrubs grew rapidly from the end of May until the beginning of July, taking advantage of approximately $20 \mathrm{hrs}$ of daylight during this period. After blooming most of the herbs quickly died. The net production $\left(25.4 \mathrm{~g} / \mathrm{m}^{2}\right)$ consists of the total growth of annual plants and the growth of leaves and sprouts of perennial plants (herbs and shrubs). This value may be slightly underestimated because the disappearance of dead material was not considered and the peaks of standing crop do not occur simultaneously in all species. It is also necessary to mention the heterogenity of the ground flora; samples taken from the sopenings « with birch and aspen were much richer than those from the dense spruce.

With respect to the biomass the mosses are dominant on the forest floor (average standing crop $178.2 \mathrm{~g} / \mathrm{m}^{2}$ ). They also contain a considerable

Table 2

Changes in standing crop of the ground flora of white spruce forest (in grams of dry matter per $\mathrm{m}^{2}$ ). Numbers represent the means of 20 samples (a total of $1.25 \mathrm{~m}^{2}$ ).

Extreme values are boldfaced. Net production was estimated from the differences of extreme values.

\begin{tabular}{|c|c|c|c|c|c|c|c|}
\hline $\begin{array}{c}\text { Plant } \\
\text { categories }\end{array}$ & $\begin{array}{l}\text { May, } \\
10-11\end{array}$ & $\underset{6}{\text { June, }}$ & $\underset{3}{\text { July, }}$ & $\begin{array}{l}\text { July, } \\
29\end{array}$ & $\begin{array}{l}\text { Aug. } \\
14-15\end{array}$ & $\begin{array}{l}\text { Avg. stan- } \\
\text { ding crop }\end{array}$ & $\begin{array}{l}\text { Net pro- } \\
\text { duction }\end{array}$ \\
\hline Lichens & 21.8 & 23.2 & 21.0 & 24.4 & 25.3 & 23.1 & 4.3 \\
\hline Mosses & 168.1 & 164.2 & 178.0 & 185.6 & 194.9 & 178.2 & 28.8 \\
\hline $\begin{array}{l}\text { Herbs } \\
\text { and shrubs } 1\end{array}$ & 12.8 & 33.5 & 38.2 & 19.2 & 14.6 & 23.7 & 25.4 \\
\hline Totals & 201.7 & 220.9 & 237.2 & 229.2 & 234.8 & 224.8 & 58.5 \\
\hline
\end{tabular}

1 Only leaves and buds of low shrubs.

accumulation of organic matter from preceding years which is difficult to differentiate from the growth of a given year. Mosses developed gradually from the beginning of June until August and achieved a rather high production $\left(28.8 \mathrm{~g} / \mathrm{m}^{2}\right)$.

The estimates for lichens can also be quite inaccurate. They were very unevenly distributed and were found in approximately half of the random samples. Moreover, the samples taken from the forest floor naturally do not include beard lichens (e.g. Parmelia auster, P. sulcata) which are very abundant in the forest. Two minor peaks in the standing crop of lichens were found at the beginning of June and in August. If these are real, they probably reflect increased humidity in early spring and in late summer during rains. Net production calculated from the difference between the extreme values of the standing crop $\left(4.3 \mathrm{~g} / \mathrm{m}^{2}\right)$ 
corresponds to about $16 \%$ of average standing crop $\left(23.1 \mathrm{~g} / \mathrm{m}^{2}\right)$. Assuming that the lichens of the taiga grow similarly to those of the tundra, i.e. about $10 \%$ annualy (Lavrenko, Andreev \& Leontev, 1955) their net production would be expected to be nearly one half $\left(2.3 \mathrm{~g} / \mathrm{m}^{2}\right)$ that measured. Total net production of the above-ground parts of plants in the ground layer of the taiga forest has a rather high value of $58.5 \mathrm{~g}$ of dry matter $/ \mathrm{m}^{2}(=585 \mathrm{~kg} / \mathrm{ha})$. It is very characteristic that mosses and lichens contribute more to the net production than herbs and low shrubs.

The crop of berries in the white spruce forest around College was rather low in 1963 (Dr. W. O. Pruit - personal communication). In three collections in late July and August an average of $107.4 \mathrm{~g}$ of fresh berries and fruits was collected from each sampling plot of $10 \mathrm{~m}^{2}$. This amount included $55 \mathrm{~g}$ or about 280 cranberries (Vaccinium vitis-idaea) and $17 \mathrm{~g}$ or 90 barries of Empetrum nigrum. The remainder was composed of Viburnum edule, Vaccinium uliginosum, Sheperdia canadensis, Geocaulon lividum and Rubus sp. The production of berries per hectare was $107.4 \mathrm{~kg}$ of fresh weight or $16.6 \mathrm{~kg}$ of dry weight. This corresponds to $75.000 \mathrm{kcal} / \mathrm{ha}$ year using the caloric value of the Alaskan cranberry, $4.516 \mathrm{kcal} / \mathrm{g}$ dry wt., as determined by West \& Meng (1966). Therefore berries accounted for more than 6\% of the net production of herbs and small shrubs. Some berries remain on the shrubs until the following year. For example in May there were still many cranberries and many berries of Empetrum from the preceding season

In addition to primary net production the forest floor offers rodents also fungi and animal food. Three collections of fungi in five sampling plots gave a mean standing crop of 9.5 fruiting-bodies $/ 100 \mathrm{~m}^{2}$ (from $4.8-27.0)$ corresponding to $66.5 \mathrm{~g}$ of fresh weight. Mushrooms in this forest appeared abundantly for 5 to 6 weeks and their fruiting-bodies persisted for more than a week. Therefore the wannual production of mushrooms can probably be estimated as six times the average standing crop, i. e. $39.9 \mathrm{~kg}$ of fresh wt. or $4.39 \mathrm{~kg}$ of dry wt. per ha. The average caloric value of mushrooms from the Alaskan taiga is $4.552 \mathrm{kcal} / \mathrm{g}$ ( $\mathrm{S} \mathrm{mith}, 1967$ ) and thus in terms of energy the production of mushrooms corresponds to some $20,000 \mathrm{kcal} / \mathrm{ha}$ year.

The production of tree seeds from September 1962 to August 1963 was precisely determined with seed traps as 626,700 spruce seeds and 2,728,300 white birch seeds per hectare ${ }^{2}$ ). In the samples collected on the ground

2) The author expresses gratitude to the Northern Forest Experiment Station (Forestry Sciences Laboratory, College) for making these unpublished materials available. He is also very grateful to Mr. Robert $W$. Funsh for his help and suggestions during the field work. 
from May to August 1963, there were fewer spruce seeds, namely $380,000 /$ ha. This difference may be explained, as consumption and storage of the seeds by rodents.

The weight of 1000 white spruce seeds was $1.982 \mathrm{~g}$ and 1000 white birch seeds $-0.305 \mathrm{~g}$. The water content was 7.35 and $14.63 \%$, respectively. Consequently, the seed fall in the forest studied in $1962 / 63$ expressed in term of dry weight was $1.86 \mathrm{~kg} / \mathrm{ha} ; 1.15 \mathrm{~kg}$ of spruce and $0.71 \mathrm{~kg}$ of birch. Intensive dispersal of spruce seeds occurred from the end of August until the middle of October and then during the dry days of May and June. The spruce cone crop in 1962/63 was not very high. In another white spruce stand in the Fairbanks area during the «seed-year" of 1958 , the production was $40,801,000$ seeds or about $75 \mathrm{~kg}$ dry wt. per ha, while in 1957 and in 1959 the production was only 341,000 and 304,000 seeds, respectively or approximately $0.6 \mathrm{~kg} / \mathrm{ha}$ (Biennial Report, 1961).

Table 3

Annual primary net production of taiga forest - above ground parts of vegetation.

\begin{tabular}{|l|c|c|c|}
\hline & $\begin{array}{c}\text { Caloric values } \\
\text { cal/g dry wt. }\end{array}$ & $\begin{array}{c}\text { Dry weight } \\
\mathrm{kg} / \mathrm{ha}\end{array}$ & $\begin{array}{c}\text { Energy content } \\
\times 10^{2} \mathrm{kcal} / \mathrm{ha}\end{array}$ \\
\hline $\begin{array}{l}\text { Herb and shrub layer } \\
\text { Lichens }\end{array}$ & 4206 & 43 & 180.9 \\
$\quad$ Mosses & 4357 & 288 & $1,254.8$ \\
$\quad$ Herbs and shrubs & 4340 & 254 & $1,102.4$ \\
Tree layer & & & 11.0 \\
$\quad$ Tree seeds & $6301^{1}$ & 2 & $(4-473)$ \\
$\quad$ Boles and whole crowns & $5330^{2}$ & $(0.6-75)$ & $7,682.5$ \\
Totals & 4931 & $1,558^{3}$ & $10,231.6$ \\
& - & 2,144 & $(10,225-10,697)$ \\
\hline
\end{tabular}

1 Caloric value of white spruce seeds. *aloric values of paper birch seeds - both determined for whole seeds with coats. "Production of black spruce was adapted from Weetman \& Harland (1964).

A summary of the data on primary net production of the taiga forest is given in Table 3. Because the contribution to net production of tree boles and crowns was not measured, a corresponding value was taken from the excellent study of the production of black spruce in Canada (W eetman \& $\mathrm{H}$ arland, 1964). Therefore, the estimate of the total net production of Alaskan taiga, 2,145 kg dry weight or $10,231,600 \mathrm{kcal} / \mathrm{ha}$ year should be considered only as an approximation. This value does not include the underground parts of plants and is not corrected for the animal consumption. If the roots in the taiga amount to some $22 \%$ of whole biomass (Rodin \& Basilevi $\check{c}, 1968$ ) then total net pro- 
duction of the spruce forest of the Alaskan interior reaches nearly 3 tons or over 13 million $\mathrm{kcal} / \mathrm{ha}$ year.

\section{Numbers and Biomass of Small Mammals}

The red-backed vole was the most numerous mammal in the spruce forest. During three series of live-trapping and removal jointly 31 backed voles (73 captures) were captured comparing with 7 tundra voles (21 captures) and 12 shrews. Backed voles and shrews were present on the sampling plot both in May, July and August, whereas tundra voles only in July and August. Moreover, red-backed voles and shrews were trapped on the almost whole grid, and tundra voles appeared only in 4 lines in the zone of openings with some birch and aspen trees.

The trap mortality was rather low for backed voles and tundra voles (6.9 and $6.3 \%$ of captures, respectively), but very high for shrews (over $83 \%$ ). For this reason only voles might be subjected to the capture-recapture analysis while for shrews simply the total catch is reported. Besides not numerous material another complication arises from a rather low survival rate of marked voles between early spring and summer trapping (interval of 43 days) and also between summer and early autumn (36 days). Hence the calculations for consecutive days of each trapping period were carried out instead of analysing cumulative data for the trapping series as a whole.

The distribution of recaptures and estimations of numbers by both methods are shown on an example of red-backed voles (Table 4). The recaptures are groupped according to the interval since last captured i.e. according to the method $" \mathrm{~B}$ * of Leslie, Chitty \& Chitty (1953). Total population estimates ( $\mathrm{J} \circ 11 \mathrm{y}, 1965)$ usually exceed markedly counted minimum numbers known to be alive. Worse still, these estimates are encumbered with a large $S . E$. due to errors in the estimation of the total number itself. This concerns particularly the first day of estimations in each series. From further analysis including survival rate, number of new animals and dilution rate, the following conclusions may be drawn: (1) the assumption of randomness of recapture was probably not fulfilled, since in one case the survival rate was higher from unity, while in two other days the numbers of newcomers is negative; (2) the number of trapped animals seems too small as reflected by a high S.E. One hectare plot was probably too small for sampling the population with such a low density.

If among all estimated numbers of backed voles only those with smaller S.E. are taken into account, then it appears that in May there 
Table 4

Distribution of red-backed voles (C. rutilus) recaptures, estimated population numbers and counted minimum numbers alive (see text for further explanations)

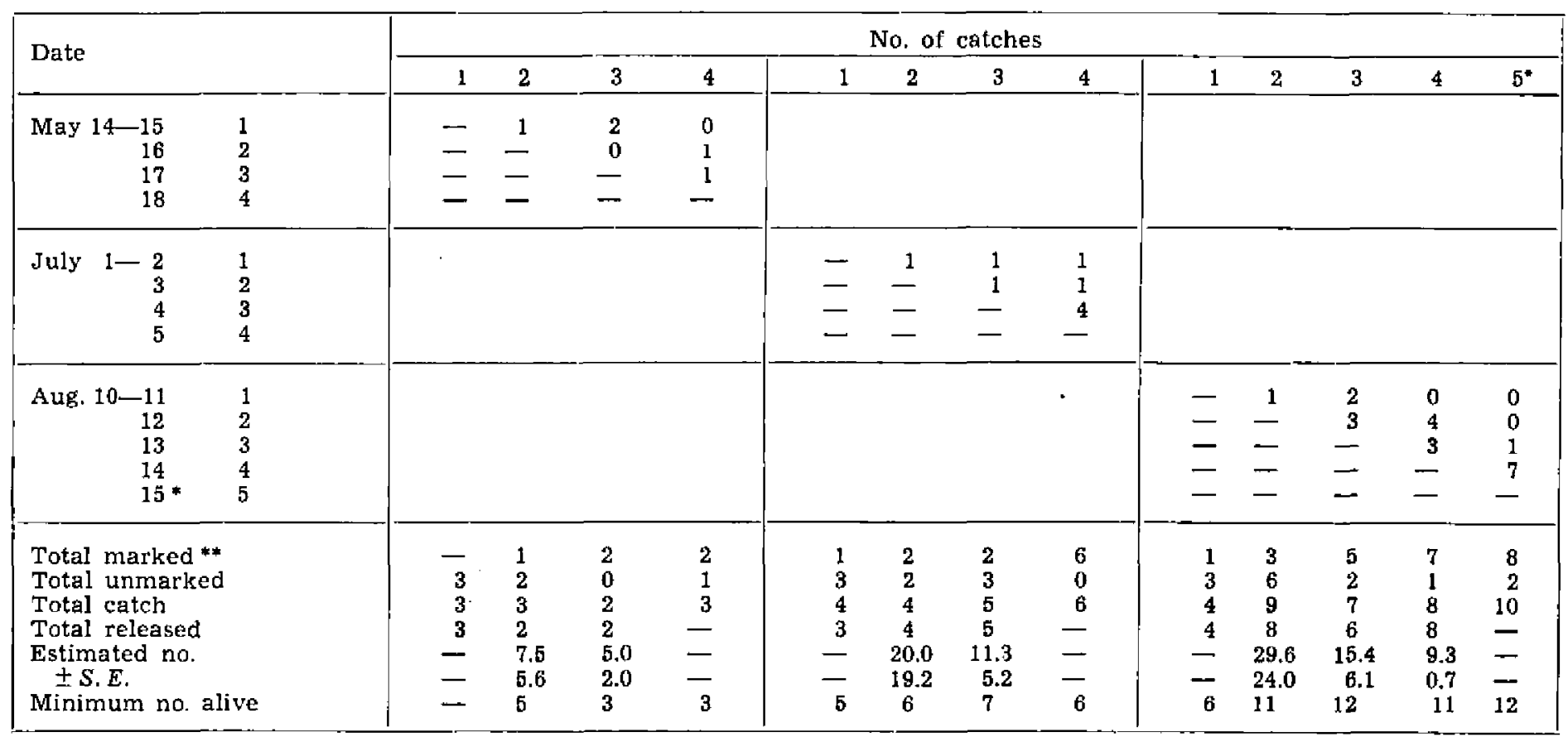

Captures during first day of removal trapping are added. ** Animals marked consecutively during three trapping pe- 
was 5.0 voles/ha, in early July $11.3 /$ ha and in the middle of August 9.3-15.4/ha. Minimum numbers alive counted for these periods reached 5, 7 and 12, respectively. Thus both estimates are rather in a good agreement only during the early spring. The third census in early autumn may be additionally verified by the removal estimate ( $Z$ i p p i $n, 1956$; $\mathrm{J}$ a $\mathrm{n}$ i o $\mathrm{n}$ et al., 1968). During three consecutive days of removal trapping (August 17-19) 15 red-backed voles were captured $(10+4+1)$. This gives an estimate of 15.7 voles/ha. After adding two voles which perished during the preceding live-trapping the total population of about 18 voles/ha is obtained - the value slightly higher than the estimate by the Jolly method (Table 4).

By comparing such various estimates it may be finally assumed that the mean density from May through August amounted to nearly 12

Table 5

Record of removal trapping of red-backed voles (C. rutilus) on 1-acre plot (Data from Pruitt, 1968*; Pruitt, Lent \& M uray, 1960, and personal comm.**). T. o. - total captures during 3-day removal, E. n. - numbers estimated by maximum likelihood.

\begin{tabular}{|c|c|c|c|c|c|c|c|}
\hline \multirow{2}{*}{ Year } & \multicolumn{3}{|c|}{ Days of trapping** } & \multicolumn{2}{|c|}{ Number/acre } & \multicolumn{2}{|c|}{ Numbers/hectare } \\
\hline & 1 & 2 & 3 & T. $\mathrm{c}^{*}$ & E.n. & T.c. & E.n. \\
\hline 1954 & 15 & 5 & 9 & 29 & $34.8^{1}$ & 71.7 & 86.0 \\
\hline 1955 & 0 & 0 & 0 & 0 & 0.0 & 0.0 & 0.0 \\
\hline 1956 & 7 & 3 & 2 & 12 & 13.0 & 29.7 & 34.1 \\
\hline 1957 & 9 & 10 & 2 & 21 & 24.7 & 51.9 & 61.0 \\
\hline 1658 & - & - & - & - & - & - & - \\
\hline 1959 & 24 & 5 & 2 & 31 & 31.3 & 76.6 & 77.3 \\
\hline 1960 & 3 & 4 & 2 & 9 & $10.8^{1}$ & 22.2 & 26.7 \\
\hline 1961 & 1 & 2 & 2 & b & $6.0^{1}$ & 12.4 & 14.8 \\
\hline Mean & 8.4 & 4.1 & 2.7 & 15.3 & 17.3 & 37.8 & $42 \cdot 8$ \\
\hline
\end{tabular}

1 Data acjusted to the average rate of removal.

backed voles, more than 3 tundra voles and about 4 shrews per one hectare (Table 6). These values are rather inaccurate but they may represent average numbers for the whole year 1963, since the trapping was started at the beginning of reproductive season when the population is the lowest, and was concluded by the end of reproduction (S e a l a nd e r, 1966), close to the annual peak of density.

One year samplings are, however, insufficient in a boreal forest because of cyclic changes in the rodent numbers. The whole cycle lasting a few years is certainly the best ecological measure ( $\mathrm{Pru}$ it t, 1968). The eight year record for the vole populations in the Fairbanks area was completed by $\mathrm{Pruitt}(1968)$. It was based on the removal trapping on one acre 
plot in another mature white spruce forest between the year 1954 and 1961. Pruitt's data are given in Table 5 where apart from the total number caught additional estimations by the maximum likelihood are shown, and the two kinds of values are recalculated for one hectare. It may be seen that the numbers of red-backed voles ranged from zero to over eighty animals per hectare. The first peak year was in 1954, and the second one in 1959. The mean density for the first cycle (1954-57) amounts to approximately $45 / \mathrm{ha}$, and for the second one to almost 40/ha. The next peak could occur in 1962 , because the density in the year of the present study (1963) was low. In the next year (1964) the number of backed voles might slightly increase but it did not reach a high level until autumn 1965 (S e a 1 a nde $r, 1967$ ). Pruit t's data are not quite comparable to those obtained in this study. One acre plot has a higher "edge effect " than one hectare plot. Efficiency of different traps may be different for Alaskan voles (Pruitt \& L u c i er, 1958), and particularly high differences could occur between snap traps and live traps (P. H. Whitney, pers. comm.). Moreover, Pruitt's samplings were made a little later, i.e. in September or late August at the yearly peak of numbers.

When mean values for the cycle based on annual peak figures amount to $40-45$ voles/ha then for the whole period of the cycle they would be probably in the range 25 backed voles/ha. The numbers found in 1963 are still two times lower than such average (Table 6).

Census of red squirrels included search of middens and watching squirrels themselves. In the studied wood three middens were present: one within the sampling grid and two other located in its nearest vicinity. The middens were huge accumulations of spruce cones bracts tripped by squirreis. Two of the mentioned middens were active throughout the whole period of study while the third one was occupied since late June. An active midden is always occupied by a single red squirrel (M. S mith, 1968) and hence the number of middens corresponds to the actual number of squirrels. Indeed, during May and June two adult squirrels were repeatedly observed in the studied forest or their callings were heard, while in July two or three squirrels were encountered. These squirrels behaved as territory holders. By the end of July and in middle of August at least three new squirrels appeared. According to pelage conditions and body size they could be distinguished as juveniles, and they apparently had now own territories. The sampling plot with surroundings covered nearly two hectares, hence the density of red squirrels in this piece of forest can be estimated approximately as $2-3$ per hectare (Table 6 ).

This wood was still too small for more general estimation of the squirrel 
population. C. H. B rin k (pers. comm.) made the census of red squirrels in a 11-hectare mature spruce forest on a river island near Fairbanks, and found there the density over $2.5 /$ ha in autumn 1962. M. S mith $(1967,1968)$ studied squirrel populations on a 21 -hectare grid in another

Table 6

Different estimates of small mammal numbers on 1-hectare plot in the taiga forest during the 1963. Some data on the cyclic fluctuations of vole and squirrel numbers are added (average values for a few year cycle in parentheses).

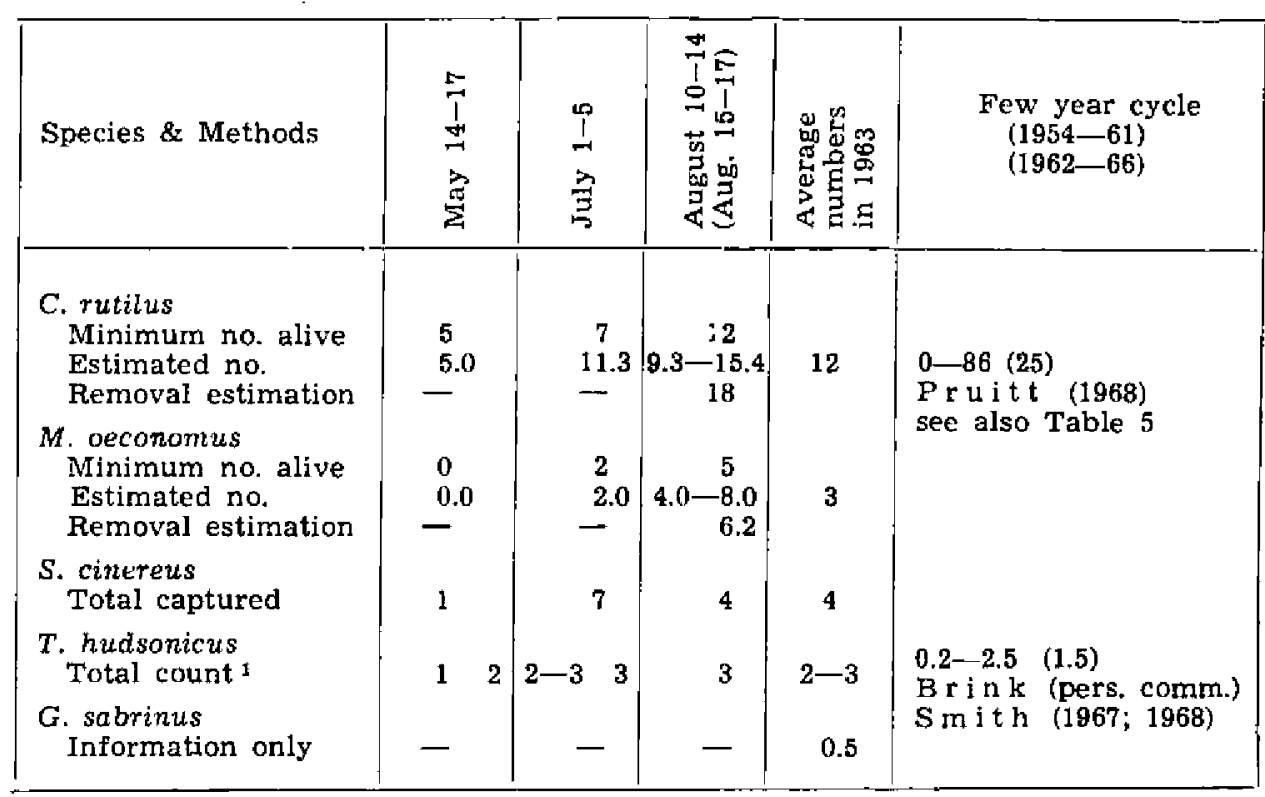

Recalculated from a 2-hectare area.

Table 7

Average body weights of small mammals from Alaskan taiga forest.

\begin{tabular}{|c|c|c|c|}
\hline Species & Time of catches & $\mathrm{N}\left(0^{\prime \prime} 0^{\prime \prime}+9 \%\right)$ & $\begin{array}{c}\text { Body wt., g } \\
\text { Avg. } \pm \text { SD }\end{array}$ \\
\hline $\begin{array}{l}\text { S. cinereus } \\
\text { C. rutilus } \\
\text { M. oeconomus } \\
\text { G. sabrinus } \\
\text { T. hudsonitus }\end{array}$ & $\begin{array}{l}\text { May-Aug. } 1963 \\
\text { May-Aug. } 1963 \\
\text { June-Aug. } 1963 \\
\text { Nov, } 1962 \\
\text { Nov.62-Aug. } 63\end{array}$ & $\begin{array}{c}8(5+-3) \\
59(35-24) \\
31(17+-14) \\
4(2+2)^{1} \\
10(9+9)^{1}\end{array}$ & $\begin{array}{r}3.76 \pm 0.56 \\
22.1 \mp 4.6 \\
31.4 \text { 市 } 9.2 \\
162.8 \text { 耳 } 5.3 \\
228.7 \pm 20.6\end{array}$ \\
\hline
\end{tabular}

1 All flying squirrels and majority of red squirrels taken by C. H. B rink (Brink \& Dean, 1066)

mature white spruce forest (Bonanza Creek Experimental Forest). During two consecutive winters (1964/65 and 1965/66) of spruce cone failure he estimated there the density as only 0.63 and $0.21 \mathrm{red}$ squirrel/ha. These 
extreme values probably do not delimitate the whole range of the fluctuations to which the number of red squirrels is subjected in the boreal forest. Such fluctuations in the neighbouring Canada occur in a cycle lasting nearly 3 years, peak years coinciding with the white spruce cone crop (K e m p \& K e it h, 1970).

The flying squirrels are strictly nocturnal (cf. Section III.4) and thus it was impossible to make their census by direct counting. For this reason an estimate kindly given by two ecologists very experienced in

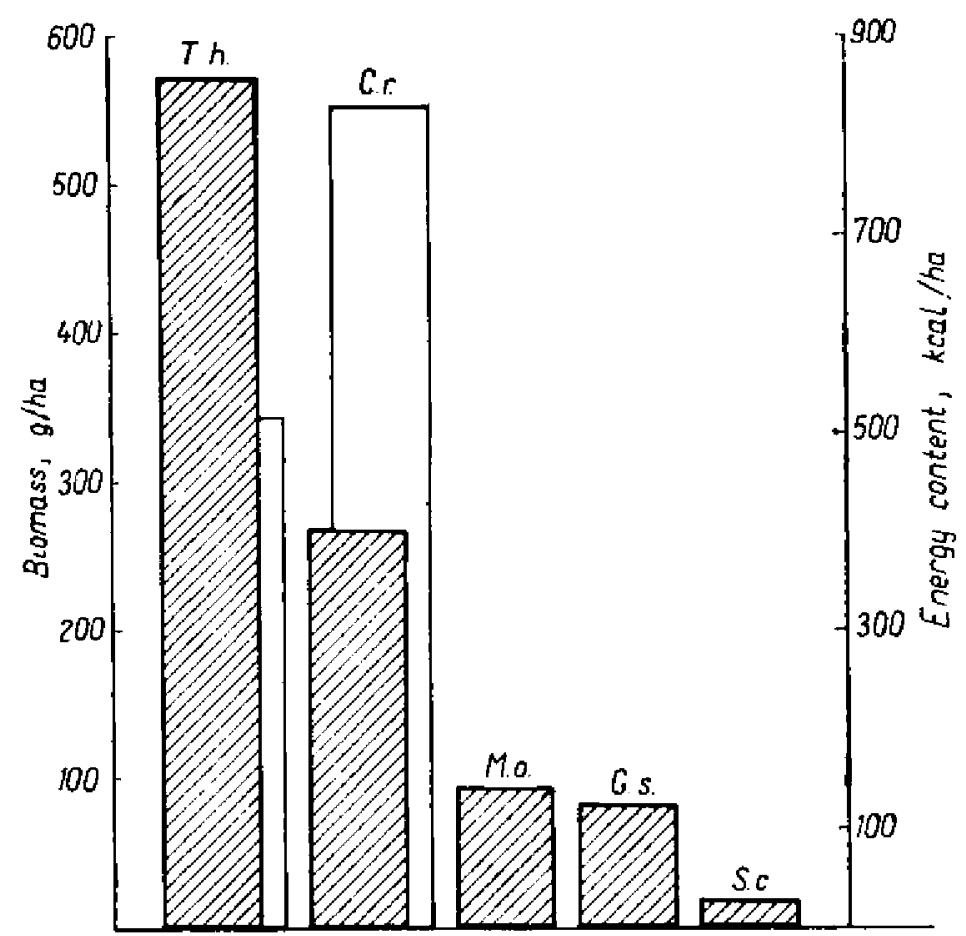

Fig. 1. Standing crop of the biomass of small mammals in the Alaskan taiga. Hatched bars represent actual values found for 1963, whereas open bars are the mean values for a few year cycle of $C$. rutilus and T. hudsonicus.

T. h. - Tamiasciurus hudsonicus, C. r. - Clethrionomys rutilus, M. o - Microtus oeconomus, G. s. - Glaucomys sabrinus, S. c. - Sorex cinereus.

studying small mammals in the taiga of this area (W. O. Pruitt and C. H. Brink, pers. comm.) was accepted. They both agreed that the density of flying squirrels was there one or less per hectare on the average (Table 6).

Table 6 contains all estimates of the small mammals numbers during the year of this study, and moreover gives some ideas on fluctuations of voles and squirrels in Alaskan taiga. There are no available data 
concerning any fluctuations of tundra voles, flying squirrels or shrews in this area. In any case it is clear that the year 1963 was characterized by very low populations of the two vole species, while the squirrels were quite abundant, especially in the studied forest.

The available data concerning body weight of small mammals in the taiga forest are summarized in Table 7 . The reported mean values represent the trappable population, i. e. wihout young animals staying in nests. The smallest trapped backed vole weighed $12.4 \mathrm{~g}$, and the smallest tundra vole $-15.8 \mathrm{~g}$. These body sizes correspond to the age of $19-20$ days, or 18-19 days in the two vole species (M or ris on, Ry ser \& $\mathrm{Strecker}, 1954)$. Thus both voles become trappable only in the age of approximately 3 weeks.

By multiplying the mean population density of mammals in white spruce forest (Table 6) by their mean body weight (Table 7) one can obtain the average standing crop of the biomass of these animals (Fig. 1). This standing crop in 1963 amounted to approximately $1,028 \mathrm{~g}$ fresh weight/ha, that corresponds to $1,540 \mathrm{kcal} / \mathrm{ha}$ ( $\mathrm{G} \mathrm{or} \mathrm{eck} \mathrm{i,} \mathrm{1965).} \mathrm{On} \mathrm{the}$ other hand, the mean standing crop for the whole cycle reaches $1,086 \mathrm{~g}$ fresh weight/ha, or $1,630 \mathrm{kcal} / \mathrm{ha}$. In the latter totals red-backed voles and red squirrels occupy dominant positions, 51 and $32 \%$ respectively (Fig. 1). The standing crop of voles can be a little overestimated since their body weights are in winter slightly lower than those given in Table 7 (Sea 1 and er, 1966).

\section{Food Habits and Natural Food Supply}

Food preference of both voles in relation to tree twigs and seeds, shrubs, herbs, mosses, lichens and fungi is given in Table 8. The figures represent means for the series of $8-10$ animals tested in each season. Individual variability in the test of choice was, however, small and concerned mainly food items poorly utilized.

Among foods produced by trees red-backed voles prefer fresh leaves of aspen, slightly less willingly consume leaves of paper birch, while fresh buds of white spruce are eaten only occasionally. Backed voles eat large amounts of white spruce seeds, husking spruce cones by themselves; in a lesser degree they utilize paper birch seeds, but they like also unripe birch fruiting cones. Among shrubs and herbs these voles may consume practically all fruits and berries, with the most preferable cranberry (Vaccinium vitis-idaea). This concernes both ripe and unripe berries, and even those from the previous year, which in next spring represent still valuable food (V. vitis-idaea, Empetrum nigrum). Greens are used by voles very little, and some buds and leaves 
Table 8

Food preference of red-backed voles (C. rutilus) and tundra voles ( $M$. oeconomus) during early spring (May), summer (late June-July) and early autumn (August). The degree of consumption is given in 4-grade scale $(0,1,2,3)$ as an average value for 8-10 tested voles. Tree seeds, lichens and fungi are ranged according to the preference of backed voles, whereas shrubs and herbs according to the choice of tundra voles.

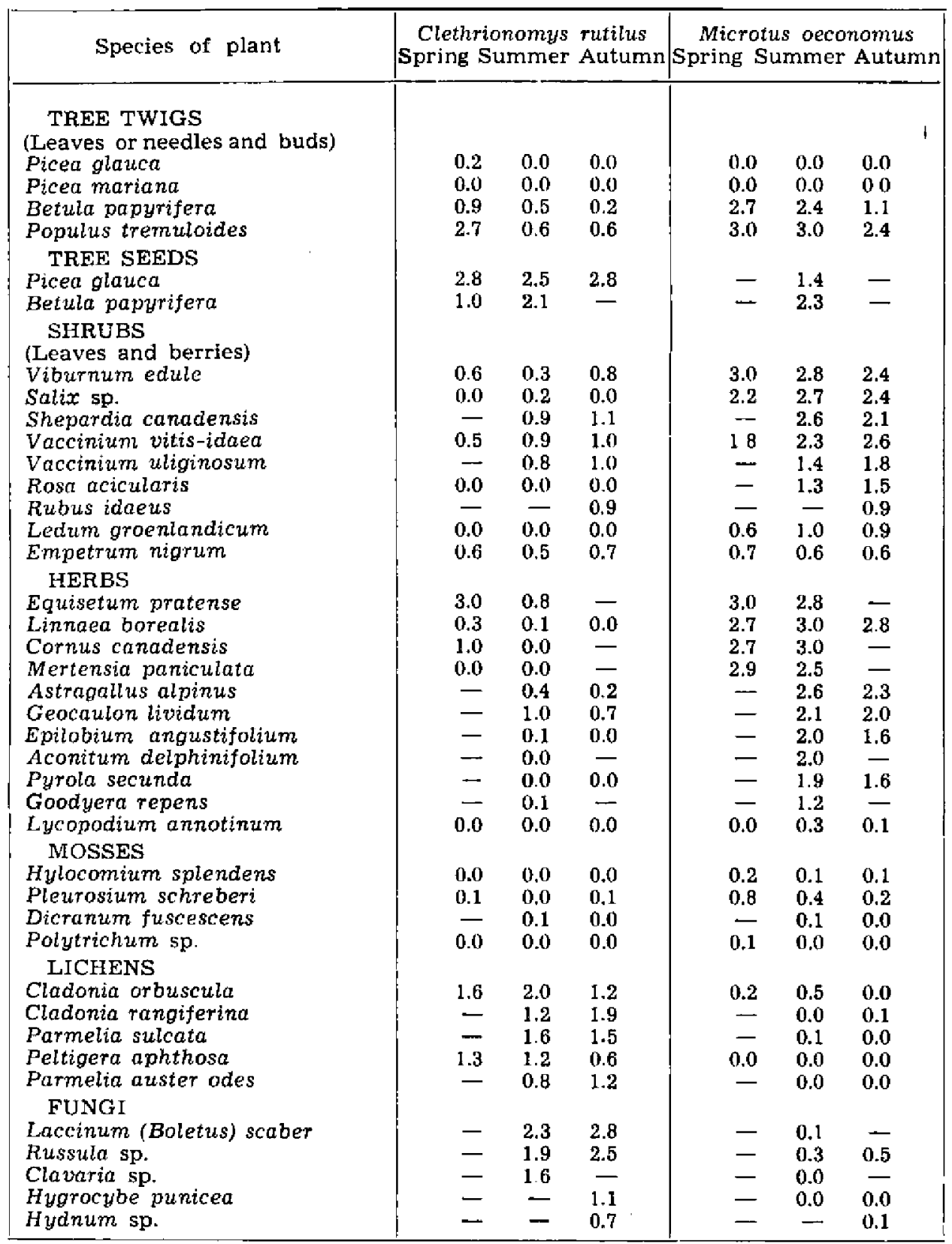


constitute only a supplement to their diet (Viburnum, Cornus, Geocaulon). The horstail (Equisetum) is the only herb consumed by red-backed voles in large amounts in spring, but later, when its sprouts became older is less utilized. These voles cannot eat practically any mosses whereas all tested lichens, both ground and beard lichens, are edible for them. The latter lichens are available for voles which can climb trees and are often encountered on branches of white spruce. In summer and autumn lichens are not willingly consumed but in winter they constitute a basic food for voles ( $\mathrm{K}$ os h k in a, 1957). Mushrooms belong to the preferable food of these animals, particularly Laccinum (Boletus) and different Russula sp.

Red-backed voles kept on a diet composed exclusively of white spruce seeds showed loss of body weight. On the other hand, the diet containing spruce seeds and lichens was of standard value and voles tolerated it well for over one month.

Tundra voles may utilize from the tree layer buds and leaves of both aspen and paper birch, particularly in spring. They collect also unripe birch fruiting cones, while spruce seeds constitute only a small supplement to the diet. These voles consume also the bark from twigs of deciduous trees and shrubs (e.g. aspen, willow).

However, the main food of the tundra vole includes greens such as leaves, buds, stems of majority of low shrubs and herbs. Among shrubs this rodent preferred Viburnum, Salix, Shepardia, Vaccinium, and from herbs Equisetum, Linnaea, Cornus, Mertensia and some grasses. Tundra voles eat also berries and fruits of almost all plants, but they do it less frequenly than backed voles. Mosses are edible to a certain degree for tundra voles, and especially in spring sporogonies and buds were partially consumed.

Seasonal changes of food preference in the two voles are small through the growing season (from spring till autumn) (Table 8). They are related rather to the availability of some plants than to changes in their palatability.

Food preference of red-backed voles and tundra voles in relation to different foods has been summarized in Fig. 2 where estimations according to the four-grade scale are computed as mean percentages for the whole categories of plant foods. This figure indicates decisively different food specialization of the two voles. Red-backed voles showed the strongest preference for berries and tree seeds, but also ate fungi and lichens (respectively: 75, 67, 55 and $40 \%$ of species tested from these categories). On the other hand, they consumed very little green food or mosses ( 7 and $1 \%$ of tested species). Tundra voles mainly preferred green food, and to some extent berries and a few tree seeds $(61,41$ 
and $35 \%$ of the species tested, respectively). Mosses, fungi and lichens were encountered only occasionally in their diet $(8.5$ and $2 \%$ of tested species).

Food habits of voles studied under laboratory conditions are in agreement with the analysis of stomach contents of animals trapped in the forest. Among 28 stomachs of red-backed voles analysed in summer berries were found in 22 , seeds in 19 , lichens in 18 , fungi in 12 , greens

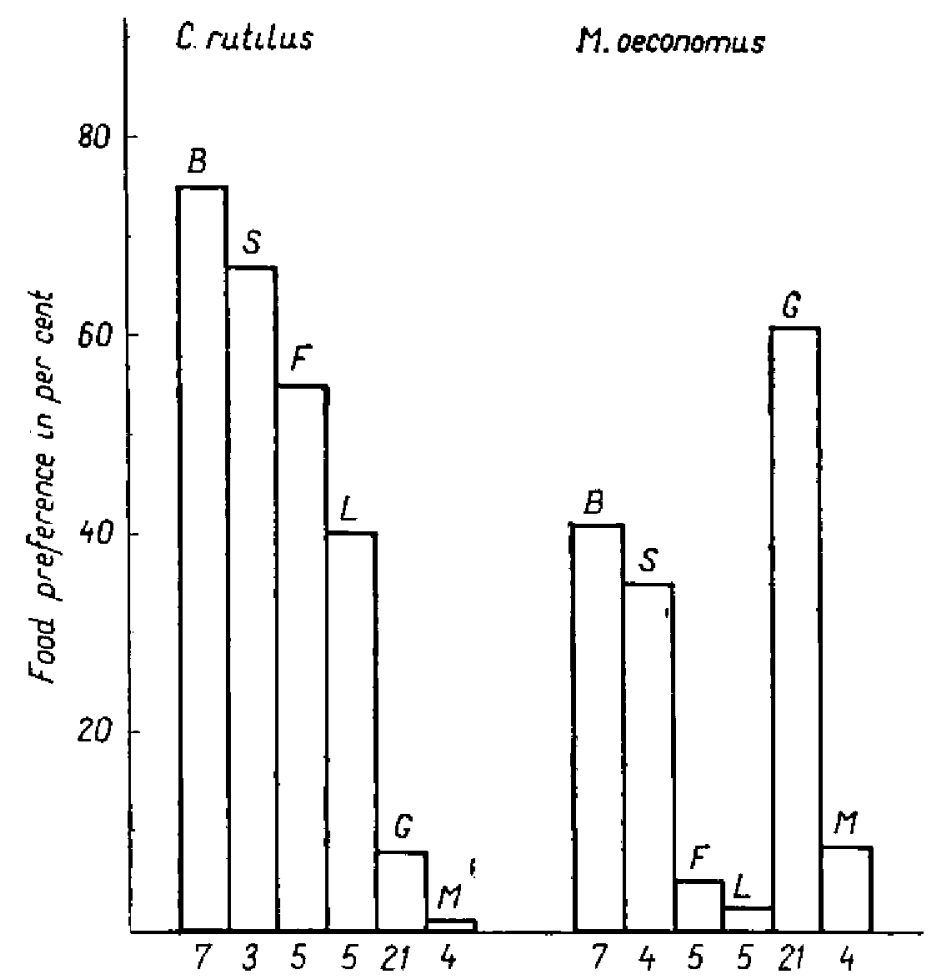

Fig. 2. Food preference of red-backed voles (C. rutilus) and tundra voles ( $M$. oeconomus) regarding different categories of plant foods. Bars - per cent of plant species eaten in a given group, figures below - number of species tested from these categories.

$B-$ berries and fruits, $S-$ tree seeds, $F-$ fungi, $L-$ lichens, $G-$ greens, $\mathrm{M}$ - mosses.

in 5 and invertebrates in 10 stomachs (frequency: 79, 68, 64, 43, 18 and $36 \%$, respectively). However, quantitative proportions of these food items differed from their frequency. By volume in the stomach contents dominated lichens, including other greens, and then seeds (33 and 28\%, respectively). Further places were occupied by berries, animal foods and fungi $(16,14$ and $9 \%$ by volume). 
Table 9

Food supply for small mammals in the white spruce forest in relation to its primary net production (all figures in $10^{3} \mathrm{kcal} / \mathrm{ha}$ year).

\begin{tabular}{|c|c|c|c|c|c|c|}
\hline Kind of food & $\begin{array}{l}\text { Net production } \\
\text { of plants }\end{array}$ & M. oeconomus & C. rutilus & $\begin{array}{l}\text { T. hudsonicus } \\
\text { G. sabrinus }\end{array}$ & S. cinereus & $\begin{array}{l}\text { All rodents } \\
\text { and shrews }\end{array}$ \\
\hline $\begin{array}{l}\text { Fungi } \\
\text { Lichens } \\
\text { Mosses } \\
\text { Herbs and shrubs }\end{array}$ & $\begin{array}{r}20 \\
181 \\
1,255 \\
1,102^{3}\end{array}$ & $\begin{array}{c}\overline{-} \\
60^{2} \\
550^{4}\end{array}$ & $\begin{array}{r}20 \\
150 \\
? \\
100^{3}\end{array}$ & $\begin{array}{r}20 \\
\frac{?}{50^{3}}\end{array}$ & $\begin{array}{l}- \\
-\end{array}$ & $\begin{array}{r}20 \\
150 \\
60 \\
600\end{array}$ \\
\hline $\begin{array}{l}\text { Tree seeds } \\
\text { Boles and whole crowns }\end{array}$ & $\begin{array}{c}11 \\
(4-473) \\
7,683\end{array}$ & $\begin{array}{c}? \\
50^{7}\end{array}$ & $\begin{array}{r}7^{6} \\
(3-322) \\
200^{8}\end{array}$ & $\begin{array}{r}5^{\mathbf{6}} \\
(2-320) \\
380^{9}\end{array}$ & $\begin{array}{l}2^{6} \\
-\end{array}$ & $\begin{array}{r}7^{6} \\
(3-325) \\
480\end{array}$ \\
\hline Totals (rounded) & 10,250 & 660 & $\begin{array}{r}480 \\
(470-790)\end{array}$ & 465 & 2 & $\begin{array}{r}1,320 \\
(1,3010-1,630)\end{array}$ \\
\hline
\end{tabular}

1 ef. Table 2 and Section III-1. \& Assuming 5\% moses production, mostly sporogonie and buds. $s$ In these berries and fruits 75,000 keal. 4 Green parts, berries and seeds of majority of plants. 5 Some berries and fruits, only. 'Caloric values of edible parts of tree seeds (Grodzinski \& $\mathrm{S}$ a wick $\mathrm{G}-\mathrm{Kapusta,1970),} \mathrm{the} \mathrm{range} \mathrm{of} \mathrm{spruce} \mathrm{seeds} \mathrm{crop} \mathrm{is} \mathrm{given}$ in paranthesis. ${ }^{7}$ Some deciduous leaves and bark, only. ${ }^{9}$ Some deciduous leaves and white spruce buds. ${ }^{9}$ White spruce buds. 
The stomachs of red squirrels $(\mathrm{N}=6)$ shot down in late summer were filled almost exclusively by spruce seeds ( $85 \%$ by volume), while fungi, few berries or fruits constituted the remainder. Intensive studies on the red squirrels just in this area (B rink \& Dean, 1966; M. Smith, 1967 ; 1968) indicate that spruce seeds, spruce buds and mushrooms constituted over $90 \%$ of their natural diet. Other miscellaneous foods included only few lichens, berries, greens and insects. The natural diet of flying squirrels ( $G$. sabrinus) in the Alaskan taiga is similar, although perhaps more diversified ( $\mathrm{B} \mathbf{r}$ in $\mathbf{k} \& \mathrm{D}$ e a $\mathrm{n}, 1966$ ).

Knowing food habits of voles and squirrels it is now better to return to the primary production of the taiga forest (cf. Section III-1) and evaluate it from the "point of view \& of these animals. The food available to small mammals was defined as athe food which is easy to find and is being chosen and eaten by these animals ( $\mathrm{Grodzinski,1968).} \mathrm{Such}$ estimate is rather coarse but still more specific than the whole primary production of the forest.

The forest floor offers to small mammals fungi, lichens, mosses, herbs and low shrubs. In the spruce forest practically all mushrooms constitute the potential food for red-backed voles and squirrels. Most lichens may be consumed by backed voles, whereas squirrels utilize them in a negligible proportion. Mosses are only additional food for tundra voles, particularly in spring and winter. Backed voles practically do not eat mosses, although not all authors agree in this respect ( $\mathrm{Sm}$ i r nov, 1970). Among herbs and low shrubs - green parts, berries and seeds of the majority of plants can be considered as the available foods for tundra voles. These voles can utilize also some bark of shrubs. Red-backed voles can eat in this layer mostly berries, fruits and some greens (e.g. horstail). The squirrels, and particularly flying squirrels, may collect some berries and fruits (Table 9).

White spruce seeds constitute the principal food for both squirrels and for red-backed voles, although the cone crop varies greatly from year to year. Paper birch seeds are suitable food for shrew and an additional constituent of the vole diet.

The most difficult to estimate as the potential food for rodents is that hidden in the tree crowns. Red squirrels consume both vegetative and flower buds of spruce in winter and spring, particularly at a failure of spruce cone crop (M. S m it h, 1967; 1968; K em p \& K e it h, 1970). Assuming that buds contain $1 / 20$ of annual production of needles their standing crop will amount to approximately $77 \mathrm{~kg}$ dry $w \mathrm{t} / \mathrm{ha}$ (We et$\mathrm{man} \& \mathrm{H}$ arland, 1964) which can be recalculated as $384,000 \mathrm{kcal} / \mathrm{ha}$ ( $\mathrm{S} \mathrm{m}$ it h, 1967. Practically all buds are available for squirrels, and those on lower branches also for red-backed voles. Deciduous trees (aspen, 
birch, willows) constitute approximately $10 \%$ admixture in the studied stand of spruce forest. They produce at least $60-75 \mathrm{~kg}$ dry wt. of leaves. Some of these leaves are available for red-backed voles, particularly in early spring, and very few also for tundra voles. The latter rodents may also eat the bark of willows and aspen.

The total available food for tundra voles may be estimated as 660,000 $\mathrm{kcal} / \mathrm{ha}$ year, for red-backed voles $-480,000 \mathrm{kcal}$ and for the two squirrels as almost $460,000 \mathrm{kcal}$. Food supplies for granivorous rodents are, however, almost twice as high $(770,000-790,00 \mathrm{kcal})$ in the year with a heavy crop of spruce cones. Owing to the different food specialization of voles, squirrels and shrews, these animals can find approximately $1,310,000-1,630,000 \mathrm{kcal} / \mathrm{ha}$ year of plant food in the Alaskan taiga. These constitute over $12 \%$ of the whole primary net production of this forest (Table 9).

In the outline of natural food for small mammals underground parts of plants are omitted, although some roots of herbs can be utilized by tundra voles (Gębczyńska, 1970). Also some animal foods, eaten mainly by shrews but constituting an important supplement in the red-backed vole diet, are not taken into consideration in this estimate. On the other hand, fungi are included in the estimate, although they do not represent primary production.

The data of Table 9 indicate, moreover, a narrow food specialization of small mammals living in the subarctic taiga. Tundra voles may exploit bulky foods, squirrels - almost exclusively concentrate food, while backed voles utilize both of them. Hence the food competition may be expected to occur between squirrels and red-backed voles, and mainly in relation to white spruce seeds.

\section{Daily Metabolism of Small Mammals}

Average daily metabolism rates $(A D M R)$, as well as minimum and maximum daily values are summarized in Table 10. ADMR represents a mean level for the daily cycle of metabolism as shown on the example of shrew (Fig. 3). The maxima and minima were calculated for each animal as the mean of three short periods (between fillings of the respirometer) with the highest and the lowest level of oxygen consumption. The maxima correspond to the periods of the most intensive activity, whereas minima represent the period of total rest (sleep). All these metabolic rates show rather large individual variability, which is probably related to the broad range of body size (Table 1).

Minimal rates of oxygen consumption, especially at $15^{\circ} \mathrm{C}$, are rather close to the basal meabolic rate measured in these voles ( $\mathrm{B}$ a s he $\mathrm{n}$ in a, 
1968 ) and squirrels (Irving, $\mathrm{Krog} \& \mathrm{M}$ onson, 1955), from subarctic areas. During daily runs the animals were, however, not in the post-absorptive state, and $15^{\circ} \mathrm{C}$ is near the lower critical temperature of Alaskan squirrels (I r ving et al., 1955), but deviates markedly from the thermoneutral zone of both voles ( $\mathrm{B}$ a shenina, 1968). The minimal metabolic rate of red backed voles measured at $15^{\circ} \mathrm{C}$ is almost identical with the resting metabolic rate in $20^{\circ} \mathrm{C}$ found by $\mathrm{M}$ or ris on \& Teitz (1953).

It is difficult to compare metabolism expressed per unit of body weight. especially when body size of these animals ranges from about $4 \mathrm{~g}$ in the shrew to $250 \mathrm{~g}$ in the squirrel. For this reason daily metabolic rates (Table 10) were converted into metabolic units of body size in $\mathrm{kcal} / \mathrm{kg}^{0.75}$ day ( $\mathrm{Kl}$ e ibe $\mathrm{r}, 1961$ ) (Table 11). ADMR is not well fitted to

Table 10

Average daily metabolic rate $(A D M R$ ) and minimum (Min.) and maximum (Max.) daily rates in small mammals from Alaskan taiga measured as oxygen consumption at $10^{\circ} \mathrm{C}$ and $15^{\circ} \mathrm{C}$.

\begin{tabular}{|c|c|c|c|c|c|c|}
\hline \multirow{2}{*}{\multicolumn{2}{|c|}{ Species \& Temp., ${ }^{\circ} \mathrm{C}$}} & \multirow{2}{*}{$\begin{array}{c}\text { Mean body } \\
\text { wt., } g\end{array}$} & \multirow{2}{*}{$\begin{array}{c}\text { Body } \\
\text { temp., }\end{array}$} & \multicolumn{3}{|c|}{ Oxygen consumption in $\mathrm{ccm} \mathrm{O}_{\mathrm{g}} \mathrm{g} \mathrm{hr}$} \\
\hline & & & & $\overline{A D M R \pm S . D}$ & Min. $\pm S . D$. & Max. $\pm S . D$ \\
\hline S. cinereus & $\begin{array}{l}10 \\
15\end{array}$ & $\begin{array}{l}3.8 \\
4.1\end{array}$ & - & $\begin{array}{l}17.41 \pm 2.54 \\
16.13 \pm 1.24\end{array}$ & $\begin{array}{l}14.53 \pm 0.61 \\
13.71 \pm 1.27\end{array}$ & $\begin{array}{l}23.23 \pm 4.50 \\
21.01 \pm 1.70\end{array}$ \\
\hline C. rutilus & $\begin{array}{l}10 \\
15\end{array}$ & $\begin{array}{l}24.2 \\
24.6\end{array}$ & $\begin{array}{l}38.9 \\
39.0\end{array}$ & $\begin{array}{l}4.87 \pm 0.70 \\
4.24 \pm 0.61\end{array}$ & $\begin{array}{l}4.12 \pm 0.70 \\
3.53 \pm 0.59\end{array}$ & $\begin{array}{l}5.54 \pm 0.78 \\
5.19 \pm 0.72\end{array}$ \\
\hline M. oeconomus & $\begin{array}{l}10 \\
15\end{array}$ & $\begin{array}{l}28.1 \\
25.5\end{array}$ & $\begin{array}{l}38.9 \\
39.5\end{array}$ & $\begin{array}{l}5.00 \pm 0.53 \\
4.62 \pm 0.88\end{array}$ & $\begin{array}{l}3.96 \pm 0.42 \\
3.70 \pm 0.64\end{array}$ & $\begin{array}{l}6.62 \pm 0.76 \\
6.08 \pm 1.11\end{array}$ \\
\hline G. sabrinus & 16 & 174.4 & 39.9 & $1.75 \pm 0.18$ & $1.32 \pm 0.14$ & $3.19 \pm 0.64$ \\
\hline T. hudsonicus & $\begin{array}{l}10 \\
15\end{array}$ & $\begin{array}{l}245.4 \\
252.3\end{array}$ & $\begin{array}{l}40.9 \\
40.9\end{array}$ & $\begin{array}{l}2.07 \pm 0.23 \\
1.75 \pm 0.32\end{array}$ & $\begin{array}{l}1.66 \pm 0.15 \\
1.52 \pm 0.29\end{array}$ & $\begin{array}{l}3.20 \pm 0.74 \\
2.27 \pm 0.44\end{array}$ \\
\hline
\end{tabular}

the exponent of 0.75 , as will be shown later ( $\mathrm{H}$ ansson \& $\mathrm{Grodz}$ i nski, 1970; Grodziński, Msc), but Kleiber's metabolic unit is a valuable base line for inter-specific comparison among small mammals (Poczopk o, 1971). From Table 11 it may be concluded that $A D M R$ measured in the temperature $10-15^{\circ} \mathrm{C}$ exceeds the predicted $B M R$ by approximately 9 times in shrews, 3 times in both voles and 2 times in both squirrels. On the other hand, the minimal metabolic level in these temperatures is higher from the predicted basal level by approximately 8 times, 2.5 times and $1.4-1.8$ times, respectively.

Body temperature $\left(T_{b}\right)$ was the most stable in red-backed voles which preserved almost identical mean $T_{b}$ in both ambient temperatures of 10 and $15^{\circ} \mathrm{C}$ and almost did not change their body temperature during daily runs (Table 10). More labile was the body temperature in tundra 
voles which showed at $10^{\circ} \mathrm{C}$ a decrease of $T_{b}$ by $0.5^{\circ} \mathrm{C}$ on the average. The two squirrels, independently of ambient temperature, maintained or slightly increased their body temperature during daily runs $\left(0.1-0.5^{\circ} \mathrm{C}\right.$ on the average).

Heat production for thermoregulation in this study can be determined only in the narrow range between $15^{\circ} \mathrm{C}$ and $10^{\circ} \mathrm{C}$. The increase of oxygen consumption per $1{ }^{\circ} \mathrm{C}$ amounted to $0.26 \mathrm{ccm} / \mathrm{g} \mathrm{hr}$ in shrews, 0.13 in backed voles, 0.08 in tundra voles, and 0.07 in red squirrels. These absolute values correspond to the following percentage of $A D M R$ : $1.59,2.98,1.65$ and $3.77 \% /{ }^{\circ} \mathrm{C}$, respectively. They are lower than those estimated from metabolism-temperature curves determined in these shrews and voles in a broader range of ambient temperature ( $\mathrm{M}$ or r ison, Ryser \& Dawe, 1959; Bashenina, 1968; Gębczyńska,

Table 11

Daily metabolic rates ( $A D M R$, Minimum and Maximum) as recalculated from oxygen consumption per unit of body weight (see Tabl. 10) into $\mathrm{kcal} / \mathrm{kg}^{0.75}$ day.

\begin{tabular}{|lc|c|c|c|}
\hline \multirow{2}{*}{ Species \& Temp., ${ }^{\circ} \mathrm{C}$} & \multicolumn{3}{|c|}{ kcal/kg0.75 day } \\
\cline { 3 - 5 } & & ADMR & Min. & Max. \\
\hline \multirow{2}{*}{ S. cinereus } & 10 & 668.3 & 567.5 & 891.7 \\
& 15 & 619.1 & 525.8 & 806.7 \\
C. rutilus & 10 & 220.6 & 186.7 & 247.0 \\
& 15 & 192.1 & 160.0 & 235.2 \\
M. oeconomus & 10 & 237.2 & 187.8 & 316.6 \\
G. sabrinus & 15 & 216.2 & 173.1 & 284.5 \\
T. hudsonicus & 10 & 130.2 & 98.2 & 237.3 \\
& 10 & 167.8 & 134.6 & 259.5 \\
\hline
\end{tabular}

1970). However, during standard measurements of resting metabolic rate these animals are devoid of the nest which shows high insulatory properties.

Daily pattern of oxygen consumption reflects well the daily rhythm of activity as recently demonstrated for several voles (G ó reck $i_{1}$ 1968; Hansson \& Grodzinski, 1970). The curves of daily metabolism of Alaskan small mammals were drawn with 2-hour intervals, and each curve represents the mean for $7-11$ runs (Figs. 3,4 and 5).

All metabolic measurements were completed in the period between the beginning of June and the end of July, when the sastronomical night * at Fairbanks $\left(65^{\circ} \mathrm{N}\right.$.lat.) lasts successively $3^{1 / 2}-2-5^{1 / 2}$ hours. The daily rhytm of the studied mammals was hence particularly instructive during the subarctic summer, as already described (Grodziński, 1966). In this period the two squirrel species showed a distinct daily rhythm 


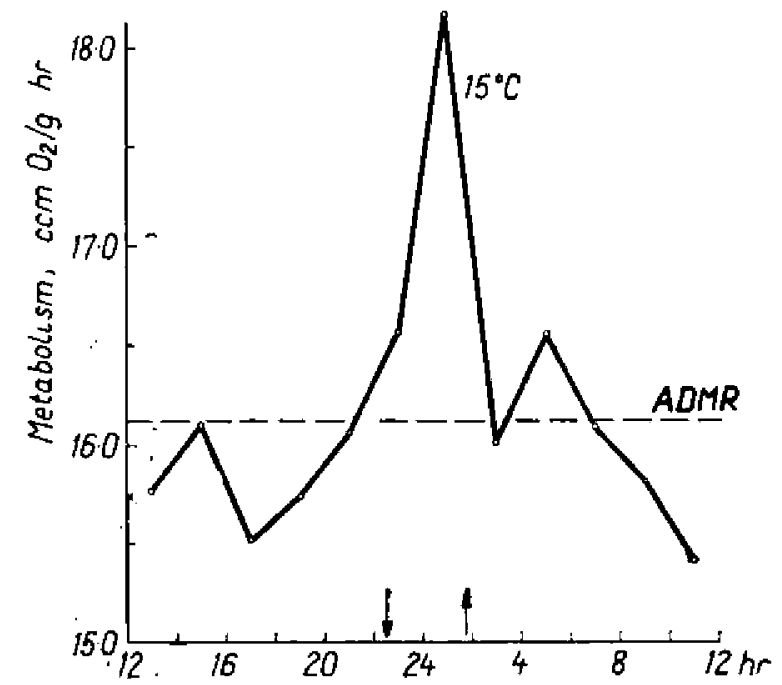

Fig. 3. Daily rhythm of metabolic rate (oxygen consumption) in shrews (Sorex cinereus) measured at $15^{\circ} \mathrm{C}$. The level of average daily metabolic rate (ADMR) is shown by the broken line. Arrows indicate the sunset and sunrise during the subarctic summer.

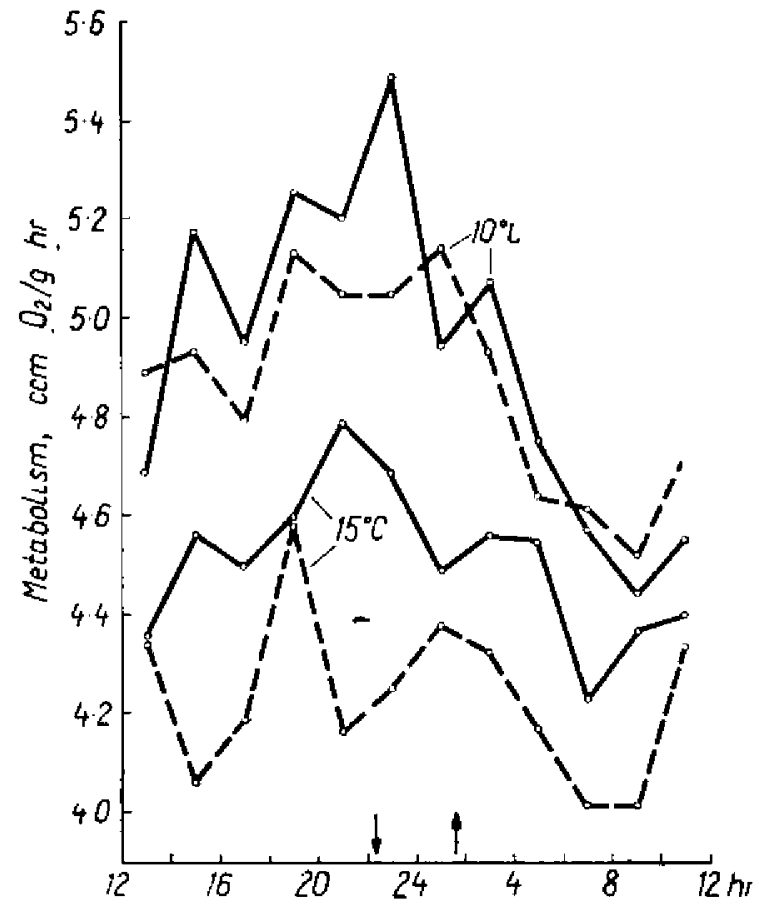

Fig. 4. Daily rhythm of metabolic rate of tundra voles, Microtus oeconomus (solid lines) and red-backed voles, Cletrionomys rutilus (broken lines) at temperatures of $10^{\circ}$ and $15^{\circ} \mathrm{C}$. Each curve represents the mean values for $10-11$ daily runs (7-10 animals). Sunset and sunrise are marked by arrows. 
while in voles this rhythm was less pronounced. The flying squirrel showed the most nocturnal manifold pattern of activity. The red squirrel had a bimodal-diurnal pattern of activity, in which two activity peaks are separated by a short night (Fig. 5). The daily rhythm of metabolism was polycyclic in shrews and in the two vole species. Shrews showed, however, a more pronounced nocturnal peak than voles in which longer periods of activity are not definitely related to the hours of darkness.

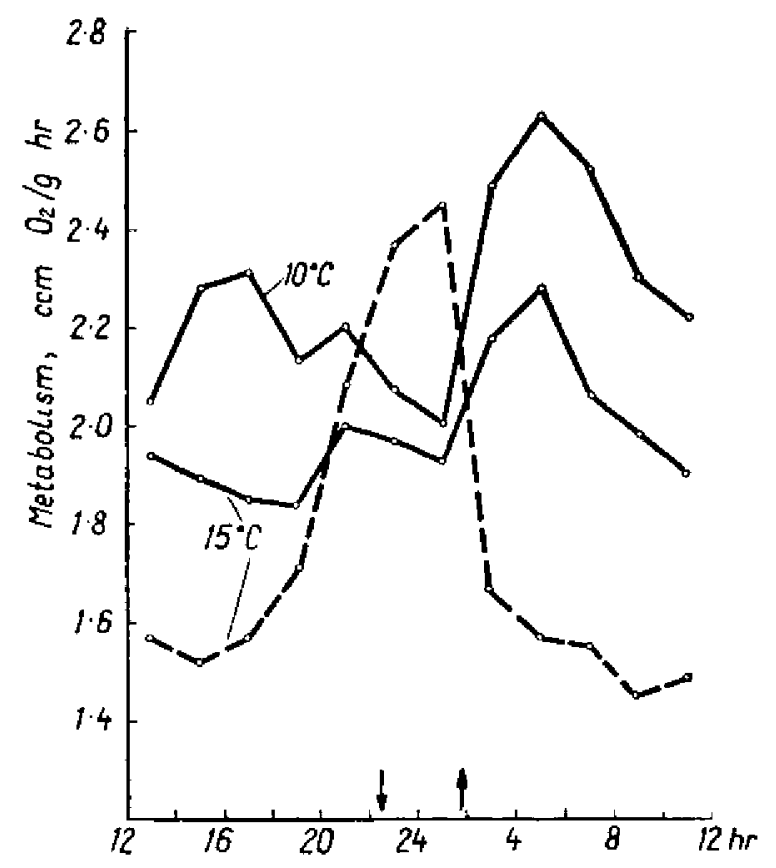

Fig. 5. Daily rhythm of oxygen consumption of red squirrels, Tamiasciurus hudsonicus (solid lines) at $10^{\circ} \mathrm{C}$ and $15^{\circ} \mathrm{C}$ and of flying squirrels, Glaucomys sabrinus (broken line) at $15^{\circ} \mathrm{C}$. Each curve represents the mean value for $7-70$ runs (4-10 squirrels). The period of night during the subarcic summer denoted by arrows.

The backed vole and tundra vole become more nocturnal with bimodal or polycyclic daily pattern in other seasons than subarctic summer (Stebbins, 1966; Peiponen, 1970).

Daily rhythms may be characterized quantitatively by the night/day ratio and the maximum/minimum ratio (Table 12 ). When the night is regarded as the six hours period from 9 p.m. to 3 a.m., and the metabolic rate is computed per one dark and per one light hour the highest degree of nocturnality is shown by the flying squirrel followed by shrews. The two vole species are markedly less nocturnal while the red squirrel is 
clearly diurnal. At lower ambient temperature $\left(10^{\circ} \mathrm{C}\right)$ the degree of nocturnality or diurnality of shrews, voles and squirrels is more pronounced than at $15^{\circ} \mathrm{C}$.

Maximum/minimum ratios are lower in voles and shrews $(1.34-1.67)$ than in squirrels, and particularly flying squirrels (2.41). In all studied mammals the ratio was slightly higher at lower ambient temperatures. However, the ratio indicates additionally that the metabolic rate in taiga mammals (except flying squirrels) increases at the period of most intensive activity only by $30-90 \%$ from the level of resting metabolic rate (Table 12).

The relationship between $A D M R$ and body weight was computed for each species and for both temperatures separately, using logarithmic values and the method of last squares (see the example of tundra voles

Table 12

Scme characters of daily activity derived (calculated) from the daily rhythm of metabolic rate measured at $10^{\circ}$ and $15^{\circ} \mathrm{C}$.

\begin{tabular}{|l|cc|cc|}
\hline \multirow{2}{*}{ Species } & \multicolumn{2}{c|}{ Max./Min. } & ratio & \multicolumn{2}{c|}{ Night/day ratio } \\
& $10^{\circ} \mathrm{C}$ & $15^{\circ} \mathrm{C}$ & $10^{\circ} \mathrm{C}$ & $15^{\circ} \mathrm{C}$ \\
\hline S. cinereus & 1.60 & 1.53 & 1.18 & 1.14 \\
C. rutilus & 1.34 & 1.47 & 1.05 & 1.02 \\
M. oeconomus & 1.67 & 1.64 & 1.07 & 1.01 \\
G. sabrinus & - & 2.41 & - & 1.49 \\
T. hudsonicus & 1.93 & 1.49 & 0.92 & 0.98 \\
\hline
\end{tabular}

1 Maximum values see Table 10. $₹$ Nighte considered as 6 -hour period from 9 p. m. to 3 a. $\mathrm{m}$.

at $15^{\circ} \mathrm{C}-$ Fig. 6). The $A D M R$ of these small mammals is a funotion of their body size but the exponent of the weight regression is in all cases closer to 0.50 than to the well known exponent of 0.75 for the basal metabolic rate (in 3 cases out of 9 the calculated exponent is statistically different from $0.75,[-0.25])$. The actual range of body size within the studied species is too smal (Table 1) for a definite ascertainment whether the intra-specific functions are different from inter-specific ones (Kleiber, 1961). On the basis of recent findings it seems, however, that also inter-specific $A D M R /$ body weight function is close to 0.50 power (Grodzinski, Msc.). For this reason all functions of $A D M R$ /body weight of Alaskan mammals were fitted to the exponent rounded off to 0.50 and then averaged for both temperatures $10^{\circ} \mathrm{C}-15^{\circ} \mathrm{C}$ (in flying squirrels this is an approximation since $A D M R$ was measured only at $15^{\circ} \mathrm{C}$ ). Providing that $A D M R$ is expressed in terms of $\mathrm{ccm} \mathrm{O}_{2} / \mathrm{g}$ 
hr and body weight $(W)$ in grams the functions assume the following appearance:
S. cinereus
$32.50 W^{-0.50}$
C. rutilus
$21.97 W-0.50$
M. oeconomus $23.86 W^{-0.50}$
G. sabrinus $\quad 25.00 W^{-0.50}$
T. hudsonicus $29.61 W^{-0.50}$

These relationships may be easily rewritten in term of kilocalories and recalculated from the unit of body weight per whole animal (see IV-1). Origins, $Y-$ intercept, of these functions allow for better than

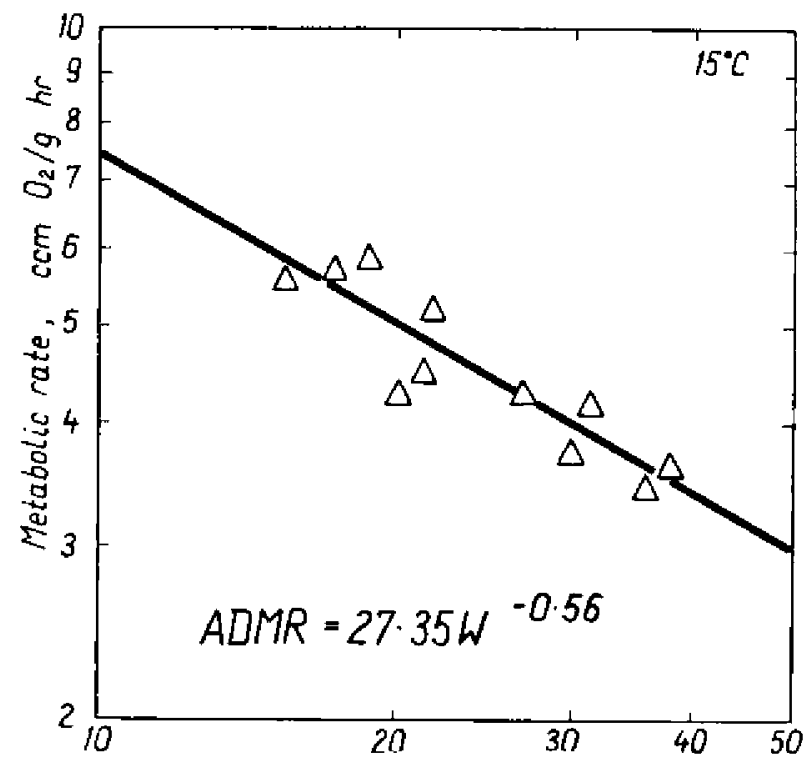

Fig. 6. Average daily metabolic rate $(A D M R)$ as a function of body size, on an example of tundra voles (Microtus oeconomus) at $15^{\circ} \mathrm{C}$. $A D M R^{\prime}$ 's are plotted against body weights (double $\log$ scale), the regression line is fitted by the least-squares method.

in Table 11 comparison of the metabolism level of various mammals. It is clearly visible that the smallest shrews had still the highest daily metabolic rate, although in the largest red squirrels its value is also very high. The lowest daily metabolism is shown by voles, particularly the red-backed vole. 


\section{DISCUSSION}

\section{Energy Budgets of Small Mammals}

Respiration (= costs of maintenance) constitutes over $97 \%$ in the balance of energy flow through populations of small mammals (Ryszkowski \& Petrusewicz, 1967; M.c Neill \&Law ton, 1970). The cost of maintenance of a vole or squirrel can be precisely described by the daily energy budget $(D E B)$ based on their average daily metabolic rate $(A D M R)$ (G r odzinski \& Górecki, 1967). The measurement of daily metabolism was first introduced by Pearson (1947) and Morrison (1948), but only in later years has been utilized for constructing $D E B$ 's (Grodziński, 1966; Grodziński \& Górec$k \mathrm{i}, 1967)$. This simple model of $D E B$ has been recently developed as a function of body size ( $\mathrm{Hanss} n$ \& $\mathrm{Grodzi}$ nski, 1970). Such $D E B$ represents a sum of energy expenditures during the time spent by an animal in the nest and during activities outside the nest, as well as some addition for the cost of female reproduction.

Daily energy budgets of small mammals from the Alaskan taiga were computed in a similar manner (Tables 13, 14) starting from the relationship of their metabolic rates and body weights (see Section III-4). The method of such calculation will be presented below using the red-backed vole ( $C$. rutilus) as an example. The energy budget elaborated in detail by $\mathrm{Górecki}$ (1968) for another Clethrionomys (C. glareolus) may serve as a guide. The equation of $A D M R$ for the backed vole (p. 258) must be first of all rewritten in terms of kilocalories and computed for the whole day (by multiplying it by the caloric equivalent of $1 \mathrm{ccm} \mathrm{O}_{2}$ and by $24 \mathrm{hr}=0.0048 \times 24$ ) and than it can be expressed per unit of body weight or the whole animal:

$$
\begin{array}{ll}
A D M R_{\mathrm{kcal} / \mathrm{g}} \text { day } & =2.531 \mathrm{~W}^{-0.50} \\
A D M R_{\mathrm{kcal} / \mathrm{an} l \mathrm{mal}} \mathrm{day} & =2.531 \mathrm{~W}^{0.50}
\end{array}
$$

The $A D M R$ measured at $10-15^{\circ} \mathrm{C}$ represents an approximation of the cost of maintenance of a non-breeding vole during the vegetation period. During the whole snow-free period, i.e. from the middle of May till end of September, the temperature at the taiga forest floor reaches on the average $11^{\circ} \mathrm{C}$ approximately, with the mean temperature of $J$ une around $14.2^{\circ} \mathrm{C}$, of July $-16.9^{\circ} \mathrm{C}$ and of August $-12.0^{\circ} \mathrm{C}$ (read off from the graph, in Pruitt, 1957). The temperature below ground surface, where vole nests are present, is slightly lower (Pr u it t, 1957). Howe- 
ver, the "group effect" of voles in the nest, and insulation of nest itself (Górecki, 1968; Gębczyński \& Gębczynska, 1971) reduce the level of metabolism more than it could be increased at ambient temperature lower by $3-5^{\circ} \mathrm{C}$. Hence the only correction calculated for $D E B$ in that season is related to the cost of breeding.

The reproduction period of backed voles in this area lasts from the middle of May till end of August (S e a l a nd e r, 1963; 1964). It may be assumed that in that period, similarly like in Eastern Siberia (P opov, 1964), more than half of vole females reproduce, having 2 to 3 litters per year. The increase in energy requirements during pregnancy and lactation may reach $58 \%$, in analogy to $C$. glareolus ( $\mathrm{K}$ a c z ma r$\mathrm{ski}$, 1966). Thus the correction for reproduction divided for both sexes amounts to $14 \%$ on the average $(50 \% \times 58 \% / 2 \times 100)$. After multiplying equation [2] by the factor 1.14 the following formula for $D E B$ during the snow-free period is obtained:

$$
D E B_{\text {kcal/animal day }}=2.855 \mathrm{~W}^{0.50}
$$

Small mammals utilize the short subarctic summer for maximal metabolic efforts but in winter tend to reduce their metabolic rate (Schwarz, 1963). Their DEB's are less expensive in winter than in summer due to different behavioural thermoregulation, seasonal changes in the metabolic rate, and mainly because they are then free of the costs of reproduction (Table 14). The $A D M R$ of similar vole species (Clethrionomys glareolus, Microtus arvalis, M. oeconomus) from lower latitudes was reduced by $17-22 \%$ in winter animals in comparison with summer ones (Górecki \& Grodziński, 1968; Gębczyńska, 1970). Even if $A D M R$ in Alaskan voles is reduced in winter only by $15 \%$ this would still mean a great heat economy during the long subarctic winter. Snow cover in white spruce forests near Fairbanks persists usually from the middle of October until middle of May (Pru it t, 1957; Vi e r e ck, 1970). Subnivean microclimate is, however, very mild and stable (P r u it , 1957). Backed voles are subnivean during the whole winter ( $P$ r u itt, 1959); they use subnivean tunnels (Morrison, 1966) and may reduce markedly their daily activity (Stebbins, 1966). On a winter day the backed vole is active outside the nest for $2-3 \mathrm{hr}(10 \%$ of day). It stays then at the ambient temperature of about $-10^{\circ} \mathrm{C}$ ( $\mathrm{Pru}$ it, 1957 ) and must increase its metabolic rate by about $7.4 \% /{ }^{\circ} \mathrm{C}$ (B a s hen in a, 1968). The additional heat production for thermoregulation outside the nest will reach only approximately $14.8 \%$ of the daily sum $\left(10 \% \times 20^{\circ} \mathrm{C} \times 7.4 \% / 100\right)$. This correction practically cancels out with the seasonal decrease of vole metabolism in 
that period. Consequently, the $D E B$ in a winter day can be estimated in approximation by the formura:

$$
D E B_{\text {kcal/animal day }}=2.50 W^{0.50}
$$

Probably $D E B$ 's of taiga voles are the most expensive at the beginning of winter, during a short period between the fall overturn and the accumulation of a critical snow thickness ( $\mathrm{Pr}$ u i t $\mathrm{t}$ 1957). Summing up daily energy budgets for the free-snow period (4-5 months) with winter $D E B$ ( $7-8$ months) the sannual \& function of the average $D E B$ may be finally obtained:

$$
D E B_{\text {keal/animal day }}=2.66 W^{0.50}
$$

The formulas for the $D E B$ of shrews and tundra voles were computed in a similar way by using additional data on their thermoregulation and daily activity (Morrison, Ryser \& Dawe, 1959; Buckner, 1964; Bashenina, 1968; Gębczyńska, 1970) (Table 13). With

Table 13

Origins (values "a") of functions describing daily metabolic rate (ADMR) and daily energy budgets ( $D E B$ ) of small mammals in terms of kcal/animal day, when their body weights are given in grams. Note that changing only the sign of the exponent

\begin{tabular}{|c|c|c|c|c|}
\hline \multirow[b]{2}{*}{$\mathrm{kcal} / \mathrm{animal}$ day $=\mathrm{a} \mathrm{W}^{0.50 *}$} & \multirow{2}{*}{$\begin{array}{l}\text { ADMR } \\
\text { measured } \\
\text { (summer) }\end{array}$} & \multicolumn{3}{|c|}{$D E B$ 's computed } \\
\hline & & $\begin{array}{c}\text { Snow-free } \\
\text { period }\end{array}$ & Winter & $\begin{array}{c}\text { Whole } \\
\text { year }\end{array}$ \\
\hline$S$. cinereus & 3.744 & 4.301 & 4.23 & 4.26 \\
\hline C. rutilus & 2.631 & 2.885 & 2.50 & 2.66 \\
\hline M. oeconomus & 2.749 & 3.133 & 2.62 & 2.87 \\
\hline G. sabrinus & 2.880 & 3.370 & - & 3.10 \\
\hline T. hudsonicus & 3.411 & $\begin{array}{l}4.195 \text { ad. } \\
3.750 \text { juv. }\end{array}$ & 3.80 & 3.85 \\
\hline
\end{tabular}
$(-0.50)$ all values may be expressed per unit of body weight (in $\mathrm{kcal} / \mathrm{g}$ day).

* $D E B=$ a $W^{0.50} \rightarrow \log D E B=\log a+0.50 \operatorname{Iog} W$.

squirrels the value was increased by some $10 \%$ as the metabolic equivalent of additional activity, which was slightly restricted in metabolic chambers. Also seasonal changes of their daily activity were taken into consideration since the activity of red squirrels is much more intense in summer (C. S $\mathrm{m}$ i th, 1968) than in winter, when at low ambient temperature of air (below $-30^{\circ} \mathrm{C}$ ) they are confined to the subnivean environment ( $\mathrm{Pruitt} \& \mathrm{Lucier}$, 1958). This is possible because both squirrels store food for winter ( $\mathrm{M} \mathrm{u} \mathrm{u} \mathrm{l}, 1968$; M. S $\mathrm{mith}$, 1968). The metabolic rate of the red squirrel probably does not show seasonal changes ( $r v i n g, K r \circ g$ \& Mons on 1955), though its fur insulation 
in winter is better by almost $30 \%$ ( $\mathrm{H} \mathrm{a} \mathrm{r}$ t, 1956). Red squirrels in boreal forests produce only one litter in the year (C. S m it h, 1968; K e m p \& K e i th, 1970), but it imposes large energy requirements for the female, especially during nursing (C. $\mathrm{S} \mathrm{mith,} \mathrm{1968).} \mathrm{In} \mathrm{constructing}$ $D E B$ of flying squirrels ( $G$. sabrinus) the seasonal changes of energy budget of southern flying squirrel ( $G$. volans), convincingly demonstrated by $\mathrm{M}$ u u I (1968), were also taken into consideration.

The functions of $D E B$ outlined in Table 13 were solved as an example (Table 14) for animals with mean body weights in the studied populations (see also Table 7). In all species energy budgets in winter were estimated as lower than those in summer, spring and early fall (Table 14). These

Table 14

Daily metabolic rates $(A D M R)$ and daily energy budgets $(D E B)$ of animals with average body weight computed according to functions summarized in Table 13 (all figures in kcal/animal day).

\begin{tabular}{|c|c|c|c|c|c|}
\hline \multirow{2}{*}{\multicolumn{2}{|c|}{ Body wt., g }} & \multirow{2}{*}{$\begin{array}{l}\text { ADMR } \\
\text { measured } \\
\text { (summer) }\end{array}$} & \multicolumn{3}{|c|}{$D E B$ 's computed } \\
\hline & & & $\begin{array}{l}\text { Snow-free } \\
\text { period }\end{array}$ & Winter & $\begin{array}{l}\text { Whole } \\
\text { year }\end{array}$ \\
\hline S. cinereus & 3.8 & 7.3 & 8.4 & 8.2 & 8.3 \\
\hline C. rutilus & $\begin{array}{l}22 \\
19 \\
20.5\end{array}$ & $\begin{array}{l}11.9 \\
11.0 \\
11.5\end{array}$ & 13.5 & 10.1 & 12,2 \\
\hline M. oeconomus & $\begin{array}{l}31 \\
25 \\
28\end{array}$ & $\begin{array}{r}15.3 \\
13.7 \\
14.6\end{array}$ & 17.4 & 13.1 & \\
\hline G. sabrinus & 163 & 36.8 & 43.0 & - & 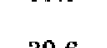 \\
\hline T. hudsonicus & $\begin{array}{l}230 \text { ad. } \\
150 \text { juv. }\end{array}$ & $\begin{array}{l}51.7 \\
41.8\end{array}$ & $\begin{array}{l}63.6 \\
45.9\end{array}$ & 57.6 & 58.4 \\
\hline
\end{tabular}

seasonal differences are more pronounced in both voles in which apart from already discussed seasonal adaptations also the mean body weight itself decreases in winter population (S e a l a nd e r, 1966; 1969).

The values of $A D M R$ based on respirometric measurements may be well checked in the studies of food metabolism while the fidelity of $D E B$ is more difficult to be verified. Red-backed voles reared on the diet containing white spruce seeds and lichens (see Section III-3) consumed daily $0.632 \mathrm{kcal} / \mathrm{g}$ and maintained rather stable body weight $(\mathrm{n}=8$; average b.w. $=23.7$ ). Assuming energy losses with feaces und urine for $17 \%$, like in C. glareolus (D roz d ż, 1968) assimilation corresponds to 0.520 $\mathrm{kcal} / \mathrm{g}$ day. Similar values for Alaskan backed voles were already re- 
ported by Morrison \& Teitz (1953). In this case total assimilation is equal to respiration because the animals did not change their body weight (production $=0$ ). Respiration calculated as $A D M R$ for backed voles of the same size (Equation [1]) is very close and amounts to $0.525 \mathrm{kcal} / \mathrm{g}$ day. Red squirrels, the same individuals which were used for $A D M R$ measurements, were kept by C. $\mathrm{H}$. B in $\mathrm{k}$ outdoors in big cages and fed with white spruce seeds. They consumed daily $0.320 \mathrm{kcal} / \mathrm{g}$ (C. H. $\mathrm{B} \mathrm{r}$ in $\mathrm{k}$, pers. comm.) corresponding to approximately $0.256 \mathrm{kcal} / \mathrm{g}$ day of assimilation when assuming $80 \%$ utilization of food energy (C. S m it h, 1968). Respiration of the same 14 squirrels determined by $A D M R$ amounted on the average to $0.243 \mathrm{kcal} / \mathrm{g}$ day, i.e. only $5.3 \%$ less. Hence in voles and squirrels both estimates are in a very close agreement and $A D M R$ may be regarded as a good and suitable measure of the costs of maintenance.

Daily energy budgets presented here (Tables 13 and 14) may be compared only with the cost of maintenance estimated by other authors for the same species. Such comparison is easy since from the function given in Table 13, DEB for animals of any body weight can be found. $D E B$ 's of tundra voles in Northern Poland are $10-11 \%$ lower both in summer and winter ( $\mathrm{G} \mathrm{ębczynska,} \mathrm{1970).} \mathrm{Energy} \mathrm{budgets} \mathrm{of} \mathrm{both}$ Alaskan voles do not deviate, however, from those found for different voles from lower latitudes (Górecki, 1966; Grodziński \& Górecki, 1967; Hansson \& Grodzinski, 1970). Energy requirement of red squirrels in winter estimated roughly from consumption of white spruce cones (Brink \& Dean, 1966; M. Smith, 1967) may be recalculated for $55-58 \mathrm{kcal} / \mathrm{animal}$ day, $i$. e. almost identical with their winter DEB's (Table 14). On the other hand energy budgets of red squirrels in British Columbia, described by watching their consumption it the wood (C. S m it h, 1968) are considerably higher. For example an adult male utilized in summer $88 \mathrm{kcal} / \mathrm{day}$ (=net energy), whereas $D E B$ calculated from summer function (Table 13) for the animal of such body weight is lower by as much as $25 \%$ and equal to $66.4 \mathrm{kcal}$.

$D E B$ 's computed in this study as functions of body weight (Table 14) are only slightly higher than those estimated earlier from $A D M R$ and resting metabolism of these animals ( $\mathrm{Grod} z \mathrm{ins} \mathrm{ki}$, 1966). The values reported previously were computed in a different way and did not include costs of breeding.

\section{Energy Flow Through Mammal Populations}

The population estimates and bioenergetic studies described in this paper enable one to compute a balance of the energy flow through small 
mammals in the Alaskan taiga. Such balance was elaborated for the population observed in 1963, but some approximate estimates were also added for the few year cycle, taking into consideration fluctuations in vole and squirrel populations (Table 15). Assimilation (=energy flow) of each population was considered as a simple sum of their respiration and production (Petrusewicz, 1967; Grodzinski, 1968). In order to obtain the cost of maintenance (=respiration) the $D E B$ values expressed in $\mathrm{kcal} / \mathrm{g}$ day (Tables 13 and 14) are simply multiplied by the number of biomass-days (Table 6 and Fig. 1). The annual respiration of voles, squirrels and shrews reaches jointly $141,400 \mathrm{kcal} / \mathrm{ha}$ (Table 15).

Table 15

Productivity of small mammals in the Alaskan taiga forest as studied in 1963 and some estimations of productivity during few year cycle (see Table 6 . for fluctuations in vole and squirrel populations). All values are given as $10^{*} \mathrm{keal} / \mathrm{ha}$ year.

\begin{tabular}{|l|c|c|c|c|}
\hline & $\begin{array}{c}\text { Production } \\
(P)\end{array}$ & $\begin{array}{c}\text { Respiration } \\
(R)\end{array}$ & $\begin{array}{c}\text { Assimilation } \\
(A)\end{array}$ & $\begin{array}{c}\text { Consumption } \\
(C)\end{array}$ \\
\hline Year of this & & & & \\
study (1963) & & & & \\
C. rutilus & 1.1 & 53.0 & 54.1 & 65.2 \\
T. hudsonicus & 0.8 & 52.5 & 63.3 & 66.6 \\
M. oeconomus & 0.4 & 16.6 & 17.0 & 24.6 \\
G. sabrinus & 0.1 & 7.2 & 7.3 & 9.1 \\
S. cinereus & 0.1 & 12.1 & 12.2 & 13.1 \\
Totals & 2.5 & 141.4 & 143.9 & 178.6 \\
\hline Few year cycle & & & & \\
(mammal density) & & & & \\
Low & & & & \\
Average & 0.6 & 37.8 & 38.4 & 46.6 \\
High & 3.4 & 177.8 & 181.2 & 224.6 \\
\hline
\end{tabular}

Production represents a very small value in relation to respiration but its accurate determination requires considerably more population data than those provided by the present study. If the production is defined as the product of average standing crop and the turnover of biomass (P e t r u s e w i c, 1967 ) then the former values are given in this paper while the latter must be borrowed from other authors. The turnover of biomass in 3 populations of other backed voles (C. glareolus) was found as 3.3-4.0/year, being at the same time lower by 10-30\% than turnover of individuals (B o bek, 1969, 1971; P et $\mathrm{r} u \mathrm{~s}$ ew ic $z$ et al., 1969). The turnover of red squirrels ( $T$, hudsonicus) may be computed from the life-table given by $\mathrm{Kem} \mathrm{p} \& \mathrm{Keith}(1970-\mathrm{p}$. 768). The average life span calculated from this table amounts to 1.201 year (14.4 months), hence the turnover of individuals in the red squirrel population in 
Alberta reaches $0.83 /$ year. The turnover of shrews (S. cinereus) was read from the survival curves given by $\mathrm{Buckner}(1966-\mathrm{p}$. 189) for a population in Manitoba. The average life span calculated from the survival curve amounts to 2.45 months, hence their individual turnover rate $=4.9 /$ year. There is no satisfactory way to convert individual turnover into biomass turnover (P etrusewicz \& M a c fadyen, 1970), the latter being usually slightly smaller in populations of small mammals (B obek, 1969, 1971; Petrusewicz et al., 1969). For this reason the following rounded of values of turnover were finally used for the calculation of production: 3.0/year for both vole species, $0.9 /$ year for both squirrels, and 5.0/year for shrews. By converting the biomass of small mammals into kilocalories $(1.5 \mathrm{kcal} / \mathrm{g}$, after Gó recki, 1965) a rough estimate of production in the studied populations was obtained (Table 15).

The total value of assimilation (sum of production and respiration) of all small mammals amounted in 1963 to nearly $144,000 \mathrm{kcal} / \mathrm{ha}$, with a dominant position occupied by the energy flow trough backed voles and red squirrels ( 37.6 and $37.0 \%$ ). The efficiency of production in relation to the total assimilation reached 2.1 and $2.2 \%$ in the populations of backed voles and tundra voles, approximately $1.5 \%$ in both squirrels and less than $1 \%$ in shrews. These efficiencies are slightly higher than those cited earlier (Ryszkowski \& Petrusewicz, 1967) when production was computed in a different way.

Consumption exceeds assimilation by the energy lost in feaces and urine of these animals (Pet $r$ usewicz, 1967). The assimilation level of natural foods energy amounts on average to $93 \%$ in shrews (B u ck$\mathrm{n}$ e r, 1964), $83 \%$ in backed voles (C. glareolus - D r oz d ż, 1968), nearly $69 \%$ in tundra voles ( $\mathrm{Geqbczynska}, 1970$ ), and may be assumed as around $80 \%$ in squirrels ( $\mathrm{S} \mathrm{mith} \mathrm{C} ., 1968$ ). By adding the energy equivalent of excrements $(7,17,31$ and $20 \%$, respectively) the whole consumption, amounting to $178,600 \mathrm{kcal} / \mathrm{ha}$ year (Table 15 ), can be obtained.

It is worth emphasizing that all elements of productivity were almost equal in the two dominating species, $i$. e. backed vole and red squirrel (Table 15). On the other hand, the average standing crop of the red squirrel biomass in the studied forest was above two times higher than that of backed voles (Fig. 1). Small voles are however, more efficient in the energy conversion due to both higher metabolic rate (respiration) and faster turnover rate (production).

The year 1963 was characterized by a low density of voles and relatively high density of red squirrels in the investigated forest. When the known fluctuations in the populations of backed voles and red squirrels 
in the Alaskan interior (Pruitt, 1968; Smith M., 1967, 1968; Brink, pers. com. - see Table 6) are taken into consideration, the energy flow during the few year cycle may be analysed (Table 15). The mean value for the whole cycle is shown in Fig. 7 (G rodzins k i, 1971). The year 1963 was below this mean value in respect of productivity of small mammals, mainly due to low numbers of voles. However, in consecutive years of the population cycle the energy flow through

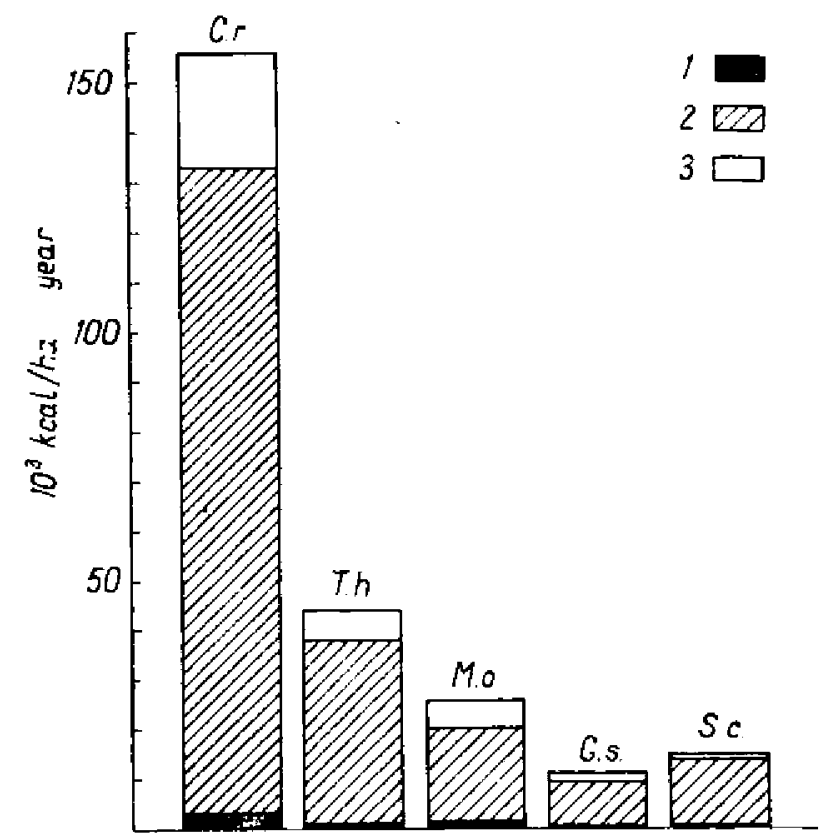

Fig. 7. Productivity of small mammals in the Alaskan taiga forest during a year with average population density.

1 - net production, 2 - costs of maintenance (respiration), 3 - excrement (feaces and urine).

$1+2$ correspond to the energy flow (assimilation), and $1+2+3$ represent the whole consumption.

C.r. - Clethrionomys rutilus, T. h. - Tamiasciurus hudsonicus, M. o. - Microtus oeconomus, G. s. - Glaucomys sabrinus, S. c. - Sorex cinereus.

small mammals may show over tenfold variations, from 38,000 to 405,000 $\mathrm{kcal} / \mathrm{ha}$ (Table 15).

The consumption in the populations of small mammals (Table 15) may be finally compared with their food available in the Alaskan taiga (Table 9) (Grodzinski, 1971). In the year of this study small mammals utilized $13.5 \%$ of their food supply (Table 16). This year was characterized by a rather low, or at most normal, crop of spruce cones 
(S m i th M., 1967), and a poor crop of berries and mushrooms (Pruitt, pers. com.), as well as already mentioned low population density of voles. It is clear that both the numbers of mammals and their food available vary in the taiga forests. Taking into account only the discussed cycles in the populations of backed voles and red squirrels (Table 6) and changes of spruce seed crop (Table 3 and 9) it may be concluded that in different years small mammals may in theory consume from 3 to $38 \%$ of the food offered them by the taiga forest. Practically they can utilize approximately $4-30 \%$, since extreme combinations from Table 16 are of small probability. Even higher fluctuations in the numbers of small rodents, especially of backed voles (Kosh k in a, 1965, 1967; S e m enov-Tyan-Shanskii, 1970), their biomass (Rejmers, 1967), as well as different foods provided by boreal forests (Novikov, 1956; Formozov, 1960) are known from numerous studies in the USSR taiga. In any case the utilization of available food by small mammals estimated in the Alaskan taiga is considerably higher than in all other

Table 16

Annual consumption of the food available to small mammals in the Alaskan taiga forest. The figures are given in per cent.

\begin{tabular}{|l|c|c|c|c|}
\hline $\begin{array}{l}\text { Food available } \\
\text { (seed crop) }\end{array}$ & \multicolumn{4}{|c|}{ Mammal numbers } \\
\hline & Low & 1963 & Average & High \\
\hline & & & & \\
Heavy & 2.9 & 11.0 & 13.8 & 30.3 \\
1963 & 3.6 & 13.5 & 17.1 & 37.4 \\
Failure & 3.6 & 13.7 & 17.3 & $\mathbf{3 8 . 0}$ \\
\hline
\end{tabular}

investigated in this respect forests and shrubs in temperate zone (Table 17). It seems that rodents and shrews in the Alaskan taiga form a community comprehensively adapted in respect of food to the supply produced by this forest. This arises mainly from diversified food habits of both voles and squirrels ( $\mathrm{Novikov}, 1956$; $\mathrm{K}$ os h kina, 1957; $\mathrm{Po-}$ pov, 1964; S m i th M., 1968), as well as from different exploitation of the same food supply. There exists for example a competition between backed voles and red squirrels regarding white spruce seeds. Voles consume, however, individual seeds dispersed on the forest floor whereas the squirrels cut whole cones on trees ( $\mathrm{R}$ a d v a n y $\mathrm{i}, 1970$ ).

This tèntative comparison of consumption of small mammals and their food supply in the Alaskan taiga requires further comments. Certain animal foods, mainly insects, constituting the main food for shrews (B u ckner, 1964) and a supplement in the diet of voles, especially of backed voles (K osh kina, 1957; Popov, 1964), were neglected in the considerations. On the other hand, the same plant foods 
are also utilized by other herbivorous mammals, granivorous birds and numerous insects. Moreover, only the annual balance was discussed whereas the annual cycle shows critical periods in respect of abundance and availability of food. The beginning of winter and very early spring may constitute such critical period for small mammals in the Alaskan white spruce forest ( $P r u i t t, 1957$ ).

The question raised in the introduction to this paper: whether food can control the rodent numbers in the taiga, remains still to be answered. Anyhow, it is likely that populations of small mammals in the taiga depend more on the food available than those in other forests of lower latitudes (Table 17). In respect of feeding two groups of mammals may be distinguished: »croppers 1963). Squirrels and shrews inhabiting the Alaskan taiga represent gatherers, the tundra vole is a typical cropper, whereas the omnivorous red-backed vole is also close to croppers. The effect of food on population numbers in these two categories of mammals is quite different ( $\mathrm{S} \mathrm{mith}$, 1971). It seems that red squirrels may be limited by both food supply and teritoriality. This is supported by detailed calculations from British Columbia (S mith C., 1968), as well as by studies in the interior of Alaska (Brink \& Dean, 1966; Smith M., 1967, 1968). Population cycles of red squirrels are well corelated with the rhythm of spruce cones production and some foods (spruce flower buds) may probably stimulate reproduction of these animals. This was recently suggested by $\mathrm{K}$ em $\mathrm{p}$ \& $\mathrm{Ke}$ ith (1970), and a similar idea concerning subarctic rodents was put forward also by $\mathrm{K}$ a l e l a (1962). On the other hand, population cycles of taiga voles are not directly related to fluctuations in the food available (S e menov-Ty an-Shanskii, 1970). Fluctuations in the number of these voles are considerably higher than those of squirrels and they are probably controlled by a self-regulatory mechanism. Koshkina (1965) believed that this population mechanism is based of the stress resulting from social interaction, whereas Se a la nder (1967) could not find a convincing proof supporting this idea.

Acknowledgements: I am greatly indebted to large number of persons who have contributed time, energy and thought to this study both in the stage of intensive collecting the materials at the University of Alaska, and during their prolonged elaboration at the Jagiellonian University in Cracow. I wish to express my deepest gratitude to Dr. P. R. M or $r$ is on and Dr. L. I r ving, Universtify of Alaska, for enabling me to carry out this research at the Institute of Arctic Biology, and for their kind interest and invaluable suggestions. I am most grateful to Dr. $W, O$. Pruitt, J $r$., University of Manitoba, and to Professor $K$. Pet r u se w ic z, Inst. of Ecology, Polish Acad, of Sci., for many stimulating discussions, and also to Dr. L. A. Viereck. Inst. of Northern Forestry, USDA, for botanical guidance and identification of plant species; to Mr. M. M orissette, M. Sc., for programming and computing all the metabolic data; to $\mathrm{Mr}$. B. Bobek, 
Table 17

Comparison of the primary net production, food available and consumption of small mammals in several types of forests and shrubs.

\begin{tabular}{|c|c|c|c|c|c|c|c|}
\hline \multirow[b]{2}{*}{ Forest ecosystem } & \multirow[b]{2}{*}{$\begin{array}{c}\text { Principal } \\
\text { small mamrials }\end{array}$} & \multicolumn{3}{|c|}{ In $10^{x} \mathrm{kcal} / \mathrm{ha}$ year } & \multicolumn{2}{|c|}{ In per cent } & \multirow[b]{2}{*}{ Reference } \\
\hline & & $\begin{array}{c}\text { Primary } \\
\text { net } \\
\text { production } \\
\left(P_{p}\right)\end{array}$ & $\left|\begin{array}{c}\text { Food avafla- } \\
\text { ble to mam- } \\
\text { mals } \\
\left(F_{a}\right)\end{array}\right|$ & $\begin{array}{l}\text { Mammal } \\
\text { consum- } \\
\text { ption } \\
\text { (C) }\end{array}$ & $F_{a} / P_{p}$ & $C / F_{a}$ & \\
\hline $\begin{array}{l}\text { Taiga forest } \\
\text { (Ficea glauca) } \\
\text { College, Alaska, USA }\end{array}$ & $\begin{array}{l}\text { C. rutilus } \\
\text { Tamiasciurus }\end{array}$ & 10,232 & $\begin{array}{c}1,320 \\
(1,320-1,630)\end{array}$ & $\begin{array}{c}179 \\
(47-494)\end{array}$ & 12.9 & $\begin{array}{c}13.5 \\
(3-48)\end{array}$ & this study \\
\hline $\begin{array}{l}\text { Finewood } \\
\text { (Vaccinio-Pinetum) } \\
\text { Mazury lakeland, } \\
\text { Poland }\end{array}$ & $\begin{array}{l}\text { C. glareolus } \\
\text { A. flavicollis }\end{array}$ & - & $2,415-7,080^{3}$ & $21-42$ & - & $0.6-1.2$ & Ryszowski (1970) \\
\hline $\begin{array}{l}\text { Pinewood } \\
\text { (Cladonio-Pinetum) } \\
\text { Mazury lakeland, } \\
\text { Poland }\end{array}$ & $\begin{array}{l}\text { C. glateolus } \\
\text { A. flavicollis }\end{array}$ & - & 1.024 & 20 & - & 1.9 & Ryszkowski (1970) \\
\hline $\begin{array}{l}\text { Oak-pine forest } \\
\text { (Pino-Quercetum) } \\
\text { Mazury lakeland, } \\
\text { Poland }\end{array}$ & $\begin{array}{l}\text { C. glareolus } \\
\text { A. flavicollis }\end{array}$ & - & $13,040^{7}$ & $75-102$ & - & $0.6-0.8$ & Ryszkowski $(1970)$ \\
\hline $\begin{array}{l}\text { Mixed \& deciduous } \\
\text { Kompinos Forest, } \\
\text { Poland }\end{array}$ & $\begin{array}{l}\text { C. glareolus } \\
\text { A. flavicollis } \\
\text { A. agrarius }\end{array}$ & - & $16,190^{3}$ & 105 & - & 0.6 & Ryszkowski (1970) \\
\hline $\begin{array}{l}\text { Oak-hornbeam forest } \\
\text { (Querco-Carpinetum) } \\
\text { Cracow, Poland }\end{array}$ & $\begin{array}{l}\text { C. glareolus } \\
\text { A. flavicallis }\end{array}$ & - & 2,050 & 95 & 一 & 4.6 & $\begin{array}{l}\text { recalculated from } \\
\text { Grodzinski (1961) } \\
\text { G orecki \& Gęb- } \\
\text { czynska (1952) }\end{array}$ \\
\hline $\begin{array}{l}\text { Beechwood } \\
\text { (Fagetum carpaticum) } \\
\text { Ojcow, Poland }\end{array}$ & $\begin{array}{l}\text { C. glareolus } \\
\text { A. flavicoltis }\end{array}$ & 43,000 & 1,950 & $\begin{array}{c}75 \\
(45-129)\end{array}$ & 4.4 & $\begin{array}{c}3.9 \\
(2-7)\end{array}$ & $\begin{array}{l}\text { Grodzinski et al. } \\
(1970) \\
\text { Drozdz (1968) }\end{array}$ \\
\hline $\begin{array}{l}\text { Spruce plantation } \\
\text { (1icea abies) } \\
\text { Bjönstorp, } \\
\text { South Sweden }\end{array}$ & M. agrestis & $\begin{array}{l}14,700- \\
-19,200\end{array}$ & $\begin{array}{c}\text { nearly } \\
\text { the same }\end{array}$ & $332-699$ & - & $1.5-2.2$ & Hansson (1971) \\
\hline $\begin{array}{l}\text { Forest plantation } \\
\text { on peat-bog } \\
\text { Augustów Forest, } \\
\text { Poland }\end{array}$ & M. oeconomus & 11,930 & $(6,650)^{4}$ & 375 & $(56)^{4}$ & $\begin{array}{l}3.1 \\
(5.6)^{\prime}\end{array}$ & Gębczyf́ska (1970) \\
\hline $\begin{array}{l}\text { Desert shrub } \\
\text { (Larrea tridentata) } \\
\text { San Simon Valley, } \\
\text { Arizona, USA }\end{array}$ & $\begin{array}{l}\text { Dipodomys } \\
\text { merriami } \\
\text { Lepus } \\
\text { californicus }\end{array}$ & 5,700 & 2,395 & 131 & 42.0 & 5.5 & Chew \& Chew (1970; \\
\hline
\end{tabular}

1 Net above-ground primary production. $2 \mathrm{C}$ - Clethrionomys, A - Apodemus. 3 All data from $\mathbf{R}$ y $\mathrm{z}$ k ows $\mathrm{k}$ (1970) are recalculated into 1 hectare; fraction which contains production of herb layer and fall of leaves and seeds (except coniferous needles). "Figures calculated roughly from data of G ęb z y n ska (1970). 
M. Sc, and Dr. A. Eomnicki for statistical assistance. Dr. Pruit and Mr C. H. Brink, M. S c., made available their unpublished data concerning vole and squirrel populations. Professor N. V. B a s h e in a, Moscow State University, was my adviser in Russian literature on taiga mammals. $D r . P$. $F$. M a y cok, University of Toronto, and Dr. P. H. Whitney, University of Alaska, critically read different sections of the manuscript.

\section{REFERENCES}

1. Bashenina N. V., 1968: Materialy k ekologii melkih mlekopitajuščih zony Evropejskoj tajgi. Uě. Zap. Permskogo Gos. Ped. Inst., 52: 3-44.

2. Biennial Report, 1961: White spruce seed production. Biennial Rep. 1960-61, pp. 8., Northern Forest Exp. Station - Juneau, Alaska.

3. Bobek B., 1969: Survival, turnover and production of small rodents in a beech forest. Acta theriol., 14, 15: 191-210.

4. B obek B., 1971: Influence of population density upon rodent production in a deciduous forest. Ann. Zool. Fennici, 8: 137-144.

5. Brink C. H. \& Dean F. C., 1966: Spruce seed as a food of red squirrels and flying squirrels in interior Alaska. J. Wildl. Mgmt., 30, 3: 503-512.

6. Buckner C. H., 1964: Metabolism, food capacity, and feeding behavior in four species of shrews. Can. J. Zool., 42: 259-279.

7. Buckner C. H., 1966: Populations and ecological relationships of shrews in tamarack bogs of Southern Manitoba. J. Mammal., 47, 2: 181-194.

8. Chew R. M. \& Chew A. E., 1970: Energy relationships of the mammals of a desert shrub (Larrea tridentata) community. Ecol. Monogr., 40, 1:1-21.

9. Drozdz A., 1966: Food habits and food supply of rodents in the beech forest. Acta theriol., 11, 15: 363--384.

10. Drożd A, 1968: Digestibility and assimilation of natural foods in small rodents. Acta theriol., 13, 21: 367-389.

11. Formozov A. N., 1960; La production de graines dans les forêts de conifères de la taiga de 1U.R.S.S, et l'envahissement de l'Europe occidentale par certaines espèces d'oiseaus. Proc. XII Int. orn. Congr., Helsinki, 1: 216-219.

12. G ębczyńska Z., 1970: Bioenergetic of a root vole population. Acta theriol., 15, 3: $33-66$.

13. Gébczynska Z. \& Gęczyński M., 1971: Insulating properties of the nest and social temperature regulation in Clethrionomys glareolus ( $\mathrm{S} \mathrm{ch} \mathrm{re-}$ be r). Ann. Zool. Fennici, 8: 104-108.

14. Golley F. B., 1961: Energy values of ecological materials. Ecology, 42, 3: $581-584$.

15. Gorecki A., 1965: Energy values of body in small mammals. Acta theriol., 10, 23: 333-352.

16. Gorecki A., 1968: Metabolic rate and energy budget in the bank vole. Acta theriol., 13, 20:341-365.

17. G orecki A. \& G ębczyńska Z, 1962: Food conditions for small rodents in a decidous forest. Acta theriol., 6, 10: 275-295.

18. Gorecki A. \& Grodzinski W., 1968: Metabolic rate and energy budgets of some voles and mice. Small Mammal Newslett, 2: 132-137.

19. Grodziński W., 1961: Metabolism rate and bioenergetics of small radents from the deciduous forest. Bull. Acad. Pol. Sci. Cl. II., 9, 12: 493-499. 
20. Grodzińs $\mathrm{ki} W$, 1966: Bioenergeties of small mammals from Alaskan taiga forest. Lynx, 6: $51-55$.

21. Grodziński $W$, 1968: Energy flow through a vertebrate population. [In: "Methods of ecological bioenergetics", Eds W. Grodzinski \& R. Z. Klek ow ski], 239-252. P. A. Sci., Warszawa - Kraków.

22. Grodzinski W., 1971: Food consumption of small mammals in the Alaskan taiga forest. Ann. Zool. Fennici, 8: 133-136.

23. Grodziński W., Bobek B., Drożdz A. \& Górecki A., 1970: Energy flow through small rodent populations in a beech forest. [In: "Energy flow through small mammal population", Eds K. Petrusewicz \& L. Ryszk ow s ki], 291-298. PWN, Warszawa.

24. Grodzinski W. \& Górecki A, 1967: Daily energy budgets of small rodents. [In: "Secondary productivity of terrestrial ecosystems", Edt. K. P etr u sewicz], I: 295-314. PWN, Warszawa - Krakow.

25. Grodzinski W. \& Sawicka-Kapusta K., 1970: Energy values of tree-seeds eaten by small mammals. Oikos, 21: 52-58.

26. Hansson L., 1971: Estimates of the productivity of small mammals in a South Swedish spruce plantation. Ann. Zool. Fennici, 8: 118-126.

27. Hansson L. \& Grodziński W., 1970: Bioenergetic parameters of the field vole, Microtus agrestis L. Oikos 21: 76-82.

28. Hart J. S., 1956: Seasonal changes in insulation of the fur. Can. J. Zool., 34: $53-57$.

29. Irving L., Krog H. \& Monson M., 1955: The metabolism of some Alaskan animals in winter and summer. Physiol. Zoöl., 28, 3: 173-185.

30. Janion M., Ryszkowski L. \& Wierzbowska T., 1968: Estimate of number of rodents with variable probability of capture. Acta theriol., 13, 16: $285-294$

31. Jolly G. M., 1965: Explicit estimates from capture-recapture data with both death and immigration - stochastic model. Biometrika, 52: 225--247.

32. Kaczmaraki F., 1966: Bioenergetics of pregnancy and lactation in the bank vole. Acta theriol., 11, 19: 409-417.

33. Kalela 0. , 1962: On the fluctuations in the numbers of arctic and boreal small rodents as a problem of production biology. Ann. Acad. Sci. Fenn. A IV, 66: $1-38$.

34. Kemp G. A. \& Keith L. B., 1970: Dynamics and regulaltion of red squirrels (Tamiasciurus hudsonicus) populations. Ecology, 51, 5: 763-779.

35. Kleiber M., 1961: The fire of life - an introduction to animal energetics. 1-454. J. Wiley \& Sons, New York - London.

36. Koshkina T. V., 1957; Sravnitel'naja ekologija ryžih polevok v severnoj tajge. Materialy po gryzunam, 5: 1-66.

37. Koshkina T, V., 1965: The population density and its importance in the numbers regulation of red vole (in Russian). Bjull. MOIP., 70. 1: 5-19

38. Koshkina T. V., 1966: On the periodically numbers changes by vole (an example of the Kola pennisula), (in Russian with English summ.). Bjull. MOIP., $71,3: 14-26$.

39. Koshkina T. V., 1967: Population regulation of the abundance of rodents (on the example of the red vole and the norwegian lemming). (in Russian with English summ.). Bjull. MOIP., 72, 6: 5-20. 
40. Lane-Petter W., 1957: Animal house equipment. [In: "The UFAW handbook on the care and management of laboratory animals", Eds $A$. N Worden \& W. La ne-Pette $r$, 23-57. UFAW, London.

41. Lavrenko E. M., Andreev V. N. \& Leontev V. L. 1955: Profil' produktivnosti nazemnoj časti pirodnogo rastitel'nogo pokrova SSSR of tundr $k$ pustyniom. Botanič. Ż., 40, 3: 415-419.

42. Leslie P. H., Chitty D. \& Chitty H. 1953: The estimation of population parameters from data obtained by means of the capture-recapture method. III. An example of the practical applications of the method. Biometrika, 40, 1-2: $137-169$.

43. Lutz H. J., 1956: Ecological effects of forest fires in the interior of Alaska. USDA. Tech. Bull., 1133: $1-121$.

44. M c N a b B. K., 1963: Bioenergetics and the determination of home range size. Amer. Naturalist, 97: 133-140.

45. McNeill S. \& Lawt on J. H., 1970: Annual production nad respiration in animal populations. Nature, 225, 5231: 472-474.

46. M or ris on P. R., 1948: Oxygen consumption in several small wild mammals. J. Cell. Comp. Physiol., 31, 1: 69-96.

47. Morrison P. R., 1951: An automatic manometric respirometer. Sci. Instr., 22, 4: $264-267$.

48. Mor $r$ is o n P. R., 1960: A caging arrangement for small mammals. J. Mammal., $41,2: 283-284$.

49. M or ris on P. R., 1966: Biometeorological problems in the ecology of animals in the aretic. Int. J. Biometeor, 10, 3: 273-292.

50. Morrison P. R. \& Grodziński W., 1968: Morrison respirometer and determination of ADMR. [In: "Methods of ecological bioenergetics", Eds W. G r odziński \& IR. Z. Klekowski], 153-163. P. A. Sci., Warszawa - Kraków.

51. Morrison P. R, Ryser F. A. \& Dawe A. R., 1959: Studies on the physiology of the masked shrew Sorex cinereus. Physiol. Zoöl., 32, 2: 256-271.

52. Morrison P. R., Ryser F. A. \& Strecker R. L., 1954: Growth and the development of temperature regulation in the tundra redback vole, $J$. Mammal., 35, 3: 376-386.

53. Morrison P. R. \& Teitz W. J., 1953: Observations on food consumption and preference in four Alaskan mammals. Arctic, 6, 1: 52-57.

54. Muul I., 1968; Behavioral and physiological influences on the distribution of the flying squirrel, Glaucomys volans. Misc. Publ. Mus. Zool. Univ. Mich., 134: $1-66$.

55. Novikov G. A., 1956: Elovye lesa kak sreda obitanija $i$ rol' $v$ ih żizni mlekopitajuščih i ptic. [In: "Rol" životnyh v žizni lesa", Edt. A. A. N a simovi c ], 6-165. MOIP, Moskva.

56. Odum E. P., 1960: Organic production and turnover in old field succession. Ecology, 41, 1: $34-49$.

57. Ovingtion J, D, 1962: Outline of general procedure to determine organic production of woodlands (Mimeo). IBP Meeting in Brussels, Annex, 33: 1-3.

58. Ovington J. D., 1965: Organic production, turnover and mineral cycling in woodlands. Biol. Rev., 40, 3: 295-336.

59. Pearson O. P., 1947: The rate of metabolism of some small mammals. Eco$\log y, 28,2: 127-145$. 
60. Peiponen V. A., 1970: Animal activity patterns under subarctic summer conditions. [In: "Ecology of the subarctic regions", Proc. Helsinki Symposium], 281-287. UNESCO, Paris.

61. Petrusewicz K., 1967: Concepts in studies on the secondary productivity of terrestrial ecosystems. [In: "Secondary productivity of terrestrial ecosystems", Edt. K. Petrus e wicz], 1: 17-50. PWN, Warszawa - Krakow.

62. Petrusewicz K. \& Andrzejewski R., 1962: Natural history of a free-living population of house mice (Mus musculus Linnaeus) with particular reference to groupings within the population. Ekol. Pol. A., 10, 5: 85-122.

63. Petrusewicz K., Andrzejewski R., Bujalska G. \& Gliwicz J., 1969: The role of spring, summer and autumn generations in the productivity of a free-living population of Clethrionomys glareolus (Schreber, 1780). [In: "Energy flow through small mammal populations", Eds $K$. Petrusewicz \& L. Ryszkowski], 235-245. PWN, Warszawa.

64. Petrusewicz K. \& M a cfadyen A., 1970: Productivity of terrestrial animals - principles and methods. IBP Handbook No. 13: 1-190. Blackwell Sci. Publ., Oxford and Edinburgh.

65. Poczopk o P., 1971: Metabolic levels in adult homeotherms. Acta theriol., $16,1: 1-21$.

66. Popov M. V., 1964: Rasprostranenie i ekologija sibirskoj krasnoj polevki (Clethrionomys rutilus $\mathrm{Pa} 11 ., 1778$ ) v Jakutii. [In: "Issledovanija po ekologii, dinamike čislennosti i boleznjam mlekopitajuščih Jakutii"l, 237-286. Izd. Nauka, Moskva.

67. Pruitt W. O., J r, 1957: Observations on the bioclimate of some taiga mammals. Arctic, 10, 3: 130-138.

68. Pruitt W. O., J r., 1959: A method of live-trapping small taiga mammals in winter. J. Mammal., 40, 1: 139-143.

69. Prujtt W. O., Jr., 1968: Synchronous biomass fluctuations of northern mammals. Mammalia, 32, 2: 172-191.

70. Pruitt W. O., Jr, Lent P. C. \& Murray B., 1960: Ogotoruk Valley mammal investigations (Interim Final Rep.), Univ. of Alaska, College.

71. Pruitt W. O., J r., \& Lucier C. V., 1958: On the relative efficiency of two kind of traps. J. Mammal., 39, 1: 157.

72. Pruitt W. O., Jr. \& L ucier C. V., 1958: Winter activity of red squirrels in Interior Alaska. J. Mammal., 39, 3: 443-444.

73. Radvanyi A, 1970: Small mammals and regeneration of white spruce forests in Western Alberta. Ecology, 51, 6: 1102-1105.

74, Rejmers N. F., 1967: Dinamika zoomassy naselenija mlekopitajuščih v sibirskoj tajge. [In: "Struktura i funkcjonalno-biogeocenotic. rol' životnogo naseIenija suši'], 46-48. MGU, Moskva.

75. Rodin L. E. \& B a sile vi N. I, 1968: World distribution of plant biomass. [In: "Functioning of terrestrial ecosystems at the primary production level", Ed. F. E. E ckard, Proc. Copenhagen Symp.], 45-51. UNESCO, Paris.

76. Ryszkowski L., 1969: Estimates of consumption of rodent populations in different pine forest ecosystems. [In: "Energy flow through small mammal populations", Eds K. Petrusewicz \& L. Ryszkowski], 281-289. PWN, Warszawa. 
77. Ryszkowski L. \& Petrusewicz K., 1967; Estimation of energy flow trough small rodent populations. [In: "Secondary productivity of terrestrial ecosystems", Edt. K. Petrusewicz], 1: 125-146. PWN, Warstawa - Krak6w.

78. Sealander J. A., 1966: Seasonal variations in hemoglobin and hematocrit values in the northern red-backed mouse, Clethrionomys rutilus dawsoni (M e r ri a m), in interior Alaska. Can. J. Zool., 44: 213-224.

79. Se a lander J. A, 1967: Reproductive status and adrenal size in the northern red-backed vole in relation to season. Int. J. Biometeor., 11, 2: 213-220.

80. Se a la nder J. A., 1969: Effect of season on plasma and urinary proteins of the northern red-backed vole, Clethrionomys rutilus. Physiol. Zoöl., 42, 3: $275-287$.

81. Semenov-Tyan-Shanskii O., 1970: Population cycles in red-backed voles. Bjull. MOIP., 55, 2: 11-26. (in Russian with English summ.).

82. Smirnov E. N., 1970: Osobennosti pitanija aziatskoj lesnoj myši, krasno-seroj i krasnoj polevok v lesach Srednego Sihote-Alinja. Ekologija, 1, 6: $106-107$.

83. Smith C. C., 1968: The adaptive nature of social organization in the genus of tree squirrels Tamiasciurus. Ecol. Monogr. 38, 1: $31-63$.

84. Sm ith M. C., 1967: Red squirrel (Tamiasciurus hudsonicus) ecology during spruce cone failure in Alaska. M. Sc. Thesis pp. 1-68, Univ. of Alaska, College.

85. S $\mathrm{m}$ ith M. C., 1968: Red squirrel responses to spruce cone failure in interior Alaska. J. Wildl. Mgmt, 32, 2: 305-317.

86. Smith M. H., 1971: Food as a limiting factor in the population ecology of Peromyscus polionotus (W a g n e r). Ann. Zool. Fennici, 8: 109-112.

87. Stebbins L. L., 1966: Seasonal variation in activity patterns of Clethrionomys rutilus and C. gapperi. Proc. IV Int. Biometeor. Congr., New Brunswick, N. J., A-6: 11 .

88. Schwarz S. S., 1963: Puti prisposoblenija nazemnyh pozvonoěnyh životnyh $k$ uslovijam sušcestvovanija $v$ subarktike. Trudy Inst. Biol. Ural. Fillial AN SSSR, 33: 1-123 (in Russian with English summ.).

89. Viereck L. A., 1970: Soil temperatures in river bottom stands in interior Alaska. [In: "Ecology of the subarctic regions", Proc. Helsinki Symposium], 223-233, UNESCO, Paris.

90. We etman G. F. \& Harland R., 1964: Foliage and wood production in unthinned black spruce in Northern Quebec. Forest Sci., 10, 1: 80-88.

91. West G. C. \& M e n g M. S., 1966: Nutrition of willow ptarmigan in northern Alaska. Auk, 83, 4: 603-615.

92. Williams O., 1962: A technique for studying Microtinae food habits. J. Mammal, 43, 3: 365-368.

93. Zippin C., 1956: An evaluation of the removal method of estimating animal populations. Biometrics, 12: 163-189.

Accepted, JuIy 1, 1971.

Department of Animal Genetics and Organic Evolution, Jagiellonian University,

Kraków 2, Krupnicza 50, Poland. 
Władyslaw GRODZIŃSKI

PRZEPEYW ENERGII PRZEZ POPULACJE DROBNYCH SSAKOW W LESIE TAJGOWYM ALASKI

\section{Streszczenie}

Las tajgowy ođ̛nacza się bardzo niską produkcja roślinna i stosunkowo wysokim zagęszczeniem ssaków, szczególnie drobnych gryzoni. Celem tej pracy bylo skompletowanie pelnego bilansu przeplywu energii dla populacji drobnych ssakbw zamieszkujących subarktyczną tajge oraz porbwnanie ich zapotrzebowania energetycznego $z$ zasobami pokarmowymi dostępnymi $w$ takim lesie. Zbadano dlatego: (1) produkcję pierwotną lasu tajgowego, (2) zagęszczenie drobnych ssaków, (3) metabolizm dobowy $i$ bioenergetyke tych zwierząt oraz (4) ich stosunki pokarmowe.

Produkcja pierwotna swierkowego lasu tajgowego (Picea glauca) $w$ interiorze Alaski (College k. Fairbanks) jest wyjatkowo niska. Osiaga ona zaledwie $10 \mathrm{mln}$. kcal/ha rok $w$ czym na produkcje roślin runa, krzewinek, mchow i porostów oraz nasion drzew przypada 2.550 tys. kcal/ha (Tabele $2 \mathrm{i} 3$ ).

Las taki posiada typowy zespół drobnych ssaków, w którym pod względem liczebności i biomasy dominuja północna nornica ruda (Clethrionomys rutilus) i wiewiórka (Tamiasciurus hudsonicus), obok nornika pólnoenego (Microtus oeconomus), ryjówek (Sorex cinereus) i polatuchy (Glaucomys sabrinus) (Ryc. 1., Tabela 7). Poslugując się różnymi metodami połowów i obserwacji oceniono średnie zagęszczenie ssaków na 1 ha lasu, które $w$ roku tych badań wynosiło około 12 nornic, 3 norniki, 4 ryjowki, 2-3 wiewiorki i 0,5 polatuchy (Tabele 4 i 5). Liczebność nornic i wiewiórek podlega jednak glębokim fluktuacjom w cyklu kilkuletnim (Tabele 5 i 6).

Gryzonie i ryjówki tajgowe odznaczają się zróżnicowana specjalizacja pokarmowa. Wiewiórkí i polatuchy odżywiają się glównie pokarmem trésciwym, nornice tresciwym i objętosciowym, natomiast norniki prawie wylącznie objętościowym (Tabela 8, Ryc. 2). Dzięki temu róźnorodne pokarmy sa dostępne dla tych ssaków w lesie tajgowym (porosty, mchy, zielonki, jagody, nasiona drzew, a także grzyby i owady), a ich lączna wartość osiaga aż 1.320 tys. kcal/ha rok tj. $12,9 \%$ produkcji pierwotnej (Tabela 9). Zasoby pokarmowe sa jeszcze znacznie wyższe $w$ latach urodzaju szyszek swierka.

Metabolizm dobowy (zużycie tlenu) drobnych ssaków badano $w$ dużych komorach i przy temperaturach zbliżonych do naturalnych. Określano zarówno średni metabolizm dobowy $-A D M R$ (Tabele 10,11 ) jak również dobowe rytmy metabolizmu, które byly szczególnie interesujące $w$ okresie lata subarktycznego (Ryc. 3, 4, 5; Tabela 12). $A D M R$ stanowi funkcje ciężaru ciala badanych zwierzat (Tabele 1, 13), przy czym wykładniki takich logarytmicznych funkcji sq zbliżone do wartości 0.50

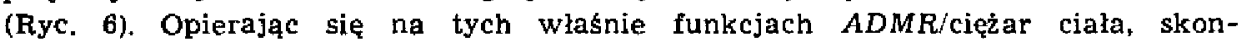
struowano dobowe budżety energetyczne $(D E B)$, które reprezentują koszty utrzymania (=respiracje) (Tabela 13). Budżety takie, dla zwierząt o średnim ciężarze ciała osiagają: ryjowki $-8,3 \mathrm{kcal}$, nornice $-12,2 \mathrm{kcal}$, norniki $-15,1 \mathrm{kcal}$, polatuchy $-39,6 \mathrm{kcal}$, wiewiórki $-58,4 \mathrm{kcal} /$ dobę (Tabela 14).

Całkowity przepływ energii (=asymilacja) przez populacje drobnych ssaków oceniono $w$ badanym roku na blisko 144 tys. kcal/ha, $z$ czego produkcja stanowila tylko 2,500 keal, a respiracja aż $141.400 \mathrm{kcal}$ (Tabela 15, Ryc. 7). Wydajnośt produkcji $w$ stosunku do asymilacji $w$ różnych populacjach wynosita od poniżej $10 \%$ do $2,2 \%$. Konsumpcja gryzoni i ryjowek osiagala rocznie $178,600 \mathrm{kcal} / \mathrm{ha}$. Przy 
kilkuletnim cyklu fluktuacji ilokciowych $w$ populacjach nornic $i$ wiewiorek. wszystkie te wartości wahają się w szerokim zakresie, produkcja od 600 do 7.800 kcal, asymilacja $38.000-400.000 \mathrm{kcal}$, a konsumpeja $47.000-500.000 \mathrm{kcal} / \mathrm{ha}$ (Tabela 15). Dlatego też $w$ różnych latach drobne ssaki moga eksploatowás od 3 do $38 \%$ zasobów pokarmowych lasu tajgowego (Tabela 16). Jest to zdecydowanie wyższy procent niż $w$ innych lasach strefy umiarkowanej, które zbadano dotychczas pod tym względem (Tabela 17). W tajdze drobne ssaki ścislej zależa więc od pokarmu, maja one także większy wplyw na funkcjonowanie tego krańcowego ekosystemu leśnego. Liczebność wiewiorek i polatuch może być prawdopodobnie regulowana przez pokarm (jakośc, obfitość - wpływ na rozród i terytorializm), podczas gdy liczebność nornic i norników jest kontrolowana głównie przez mechanizmy populacyjne. 